\title{
Heterocyclic bismuth(III) compounds with transannular NBi interactions as catalysts for the oxidation of thiophenol to diphenyldisulfide
}

DOI:

10.1039/C7CY00521K

\section{Document Version}

Accepted author manuscript

Link to publication record in Manchester Research Explorer

Citation for published version (APA):

Toma, A. M., Ra, C. I., Pavel, O. D., Hardacre, C., Rüffer, T., Lang, H., Mehring, M., Silvestru, A., \& Pârvulescu, V. I. (2017). Heterocyclic bismuth(III) compounds with transannular NBi interactions as catalysts for the oxidation of thiophenol to diphenyldisulfide. Catalysis Science and Technology. https://doi.org/10.1039/C7CY00521K

Published in:

Catalysis Science and Technology

\section{Citing this paper}

Please note that where the full-text provided on Manchester Research Explorer is the Author Accepted Manuscript or Proof version this may differ from the final Published version. If citing, it is advised that you check and use the publisher's definitive version.

\section{General rights}

Copyright and moral rights for the publications made accessible in the Research Explorer are retained by the authors and/or other copyright owners and it is a condition of accessing publications that users recognise and abide by the legal requirements associated with these rights.

\section{Takedown policy}

If you believe that this document breaches copyright please refer to the University of Manchester's Takedown Procedures [http://man.ac.uk/04Y6Bo] or contact uml.scholarlycommunications@manchester.ac.uk providing relevant details, so we can investigate your claim.

\section{OPEN ACCESS}




\section{Accepted Manuscript}

This article can be cited before page numbers have been issued, to do this please use: A. M. Toma, C. I. Rat, O. D. Pavel, C. Hardacre, T. Rueffer, H. Lang, M. Mehring, S. D. Anca and V. I. Parvulescu, Catal. Sci. Technol., 2017, DOI: 10.1039/C7CY00521K.

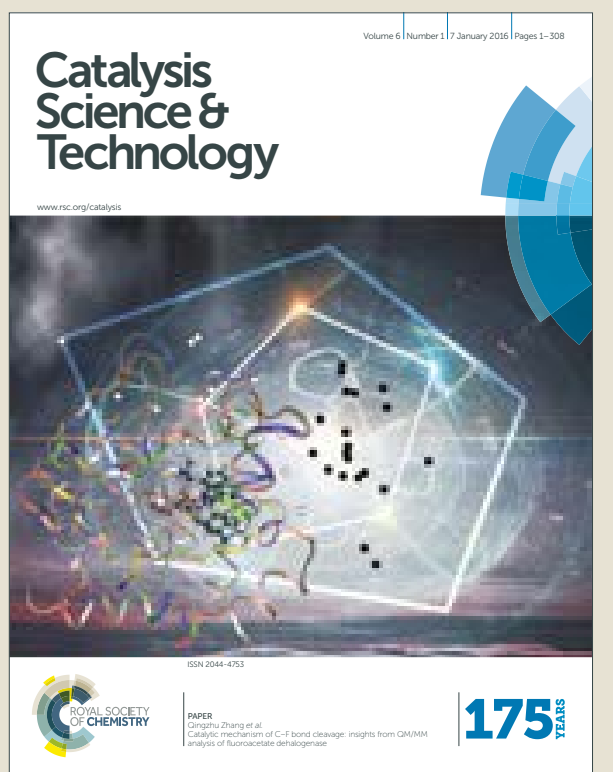

This is an Accepted Manuscript, which has been through the Royal Society of Chemistry peer review process and has been accepted for publication.

Accepted Manuscripts are published online shortly after acceptance, before technical editing, formatting and proof reading. Using this free service, authors can make their results available to the community, in citable form, before we publish the edited article. We will replace this Accepted Manuscript with the edited and formatted Advance Article as soon as it is available.

You can find more information about Accepted Manuscripts in the author guidelines.

Please note that technical editing may introduce minor changes to the text and/or graphics, which may alter content. The journal's standard Terms \& Conditions and the ethical guidelines, outlined in our author and reviewer resource centre, still apply. In no event shall the Royal Society of Chemistry be held responsible for any errors or omissions in this Accepted Manuscript or any consequences arising from the use of any information it contains. 


\section{Catalysis Science \& Technology}

\section{ARTICLE}

\section{Heterocyclic bismuth(III) compounds with transannular $\mathbf{N} \rightarrow \mathbf{B i}$ interactions as catalysts for the oxidation of thiophenol to diphenyldisulfide}

Received 00th January 20xx, Accepted 00th January 20xx

DOI: $10.1039 / \times 0 \times x 00000 x$ www.rsc.org/

\author{
Ana M. Toma, ${ }^{a}$ Ciprian I. Raț, ${ }^{a}$ Octavian D. Pavel, ${ }^{b}$ Christopher Hardacre, ${ }^{c, d}$ Tobias Rüffer, ${ }^{e}$ Heinrich \\ Lang, ${ }^{e}$ Michael Mehring, ${ }^{f}$ Anca Silvestru, ${ }^{a, *}$ and Vasile I. Pârvulescu, ${ }^{b}{ }^{*}$
}

\section{Introduction}

The conversion of thiols to disulfides has attracted a continuously increased interest in recent years ${ }^{1}$ due to the importance of disulfides in biology, mainly based on their antioxidant properties and their interconversion reactions in living systems, ${ }^{2}$ fine chemicals synthesis, e.g. pharmaceuticals and pesticides, ${ }^{3}$ as well as in refinery processes and rubber vulcanization. $^{4}$ Various methods, including catalysis (homogeneous, ${ }^{5}$ heterogeneous ${ }^{6}$ or photo-catalysis ${ }^{7}$ ), or noncatalytic oxidation procedures, e.g. with sodium periodate in a solid state reaction, ${ }^{8}$ or benzyltriphenylphosphonium peroxymonosulfate under reflux in acetonitrile ${ }^{9}$, as well as electrochemical techniques ${ }^{10}$ were employed (Table 1 ).

Constant efforts were made for the identification of

\footnotetext{
a. Supramolecular Organic and Organometallic Chemistry Centre, Faculty of Chemistry \& Chemical Engineering, Chemistry Department, Babes-Bolyai University, RO-400028 Cluj-Napoca, Romania; E-mail: ancas@chem.ubbcluj.ro

b. Faculty of Chemistry, Department of Organic Chemistry, Biochemistry and Catalysis, University of Bucharest, 4-12 Regina Elisabeta Av., S3, 030018

Bucharest, Romania; E-mail: vasile.parvulescu@chimie.unibuc.ro

c. Queen's University Belfast, The QUILL Centre/School of Chemistry and Chemical Engineering, Belfast, Northern Ireland, UK

d. The University of Manchester, School of Chemical Engineering \& Analytical

Science, Manchester, UK E-mail: C.Hardacre@manchester.ac.uk

e. Technische Universität Chemnitz, Institut für Chemie, Anorganische Chemie, D09107 Chemnitz, Germany; E-mail: heinrich.lang@chemie.tu-chemnitz.de

f. Technische Universität Chemnitz, Institut für Chemie, Koordinationschemie, $D$ 09107 Chemnitz, Germany, E-mail: michael.mehring@chemie.tu-chemnitz.de Electronic Supplementary Information (ESI) available: [details of any supplementary information available should be included here]. See DOI: 10.1039/x0xx00000x
}

appropriate systems consisting of the oxidant, solvent and catalyst, in order to increase the selectivity, i.e. to avoid the over-oxidation to by-products such as sulfoxides, thiosulfinates, thiosulfonates or sulfonic acids, but also the contamination with heavy metals or the toxicity, or to reduce the reaction time and the effective costs of the process. ${ }^{7,11}$ Thus, the replacement of halogens, ${ }^{12}$ transition metal containing systems, ${ }^{13}$ ammonium persulfate ${ }^{14}$ or $\mathrm{Bu}_{3} \mathrm{SnOMe} / \mathrm{FeCl}_{3}{ }^{15}$ with air, molecular oxygen, ${ }^{16} \mathrm{H}_{2} \mathrm{O}_{2},{ }^{17}$ functionalized ionic liquids $\left[\mathrm{HSO}_{3} \mathrm{~N}\left(\mathrm{C}_{2} \mathrm{H}_{4} \mathrm{OSO}_{3} \mathrm{H}\right)_{3}\right]^{11 \mathrm{a}}$ or even nitric oxide ${ }^{18}$ is highly desired. Among these, of special interest is the air oxidation which is a sustainable, cheap, easy to handle and an environmentally friendly process. ${ }^{19}$

Generally, chlorinated solvents (dichloromethane), ${ }^{20}$ methanol, water, water-alcohol mixtures, or acetonitrile were used as a reaction medium in homogeneous processes. Different catalysts based on transition metals ( $\mathrm{Fe}, \mathrm{Co}, \mathrm{Pd}, \mathrm{Pt}$, $\mathrm{Au}, \mathrm{Mo}, \mathrm{Ru}, \mathrm{Rh}$, etc.), despite their high selectivity and short reaction times, ${ }^{6 a, 21}$ are not always appropriate for pharmaceutical or biologically active products, ${ }^{22}$ mainly due to the toxicity of heavy metals. Therefore, heterogeneous systems using either nanoparticles of metal oxides $\left(\mathrm{Fe}_{2} \mathrm{O}_{3}{ }^{11 \mathrm{a}}\right.$ $\mathrm{NiFe}_{2} \mathrm{O}_{4}{ }^{23} \mathrm{Bi}_{2} \mathrm{WO}_{6}{ }^{7}$ ), graphite oxide, ${ }^{6 \mathrm{~b}} \mathrm{Fe}(\mathrm{BTC})$ (BTC: 1,3,5benzenetricarboxylate) ${ }^{6 a}$ or iron phthalocyanine immobilized on graphene oxide ${ }^{24}$ are preferred. Enzymes ${ }^{25}$ and biomimetic iron(III)-tetraphenylporphyrin ${ }^{26}$ were also investigated as selective catalysts in these reactions.

These state of the art examples demonstrate that there is still need for the optimization of the procedures for the 
oxidation of thiols to disulfides and for readily available, safe, stable and cheap catalysts. In this respect bismuth in the readily available, non-toxic and easy to handle oxidation states $\mathrm{Bi}(0)$ or $\mathrm{Bi}(\mathrm{III})$ has already demonstrated its capability as catalyst for a large variety of organic transformations including oxidation, reduction, $\mathrm{C}-\mathrm{C}$ and $\mathrm{C}-\mathrm{E}(\mathrm{E}=\mathrm{O}, \mathrm{N}, \mathrm{S}$, halogen) bond formation. ${ }^{27}$ Aromatic and aliphatic thiols were oxidized to disulfides with $\mathrm{Bi}\left(\mathrm{NO}_{3}\right)_{3}$ in high yields also, ${ }^{28}$ but only few reports indicate organobismuth(III) compounds as catalysts, ${ }^{29}$ due to a supposed low stability of the C-Bi bond. ${ }^{27 d}$

Bulky ligands ${ }^{30}$ or organic groups bearing donor atoms capable for intramolecular coordination ${ }^{31}$ were used to stabilize main group metals, including bismuth in low oxidation states. Neutral or cationic hypercoordinated diorganobismuth(III) species based on a tetrahydrodibenzo[c,f][1,5]thiabismocine framework were reported as active species in Mannich reactions, ${ }^{32}$ or for the stereoselective synthesis of $(E)-\alpha, \beta$-unsaturated ketones, ${ }^{33}$ while compounds based on a tetrahydrodibenzo[c, $\mathrm{f}][1,5]$ azabismocine framework, e.g. ionic $\left.{ }^{\mathrm{t}} \mathrm{BuN}\left(\mathrm{CH}_{2} \mathrm{C}_{6} \mathrm{H}_{4}\right)_{2} \mathrm{Bi}\right]^{+}\left[\mathrm{B}\left(\mathrm{C}_{6} \mathrm{~F}_{5}\right)_{4}\right]^{-}$and neutral $\left[\mathrm{C}_{6} \mathrm{H}_{11} \mathrm{~N}\left(\mathrm{CH}_{2} \mathrm{C}_{6} \mathrm{H}_{4}\right)_{2}\right] \mathrm{BiL}\left(\mathrm{L}=\mathrm{BF}_{4}, \mathrm{OSO}_{2} \mathrm{C}_{8} \mathrm{~F}_{17}\right)$ were used in allylation reactions of aldehydes and Mukaiyama aldol reactions. $^{34}$

A special attention was paid to the environmental impact of the solvents used in the catalytic processes ${ }^{35,36}$ and different alternatives to the organic solvents were proposed, including ionic liquids (ILS). ${ }^{37}$

Besides other advantages, ILs contribute to the stabilization and the reuse of the catalyst and allow a good separation of the organic product by distillation. Selective catalytic oxidations, including the S-S coupling of thiols to disulfides took the advantage of using ILs. ${ }^{37 a, 38}$ They have also been used for the S-S coupling of thiols to disulfides in combination with various oxidizing agents in the following systems: [bmim][methylselenite] with air, ${ }^{39}$ [bmim]Br with $\mathrm{K}_{2} \mathrm{~S}_{2} \mathrm{O}_{8},{ }^{40}[\mathrm{bmim}]\left[\mathrm{BF}_{4}\right]^{41}$ and $\left[\mathrm{BPy}_{\mathrm{BBF}}{ }^{42}\right.$ with $\mathrm{H}_{2} \mathrm{O}_{2}$ or WO $\left(\mathrm{O}_{2}\right)_{2} \cdot$ Phen $\cdot \mathrm{H}_{2} \mathrm{O}{ }^{43}\left(\left[\mathrm{Hnmp}^{4} \mathrm{BF}_{4}\right]\right.$ with $\mathrm{H}_{2} \mathrm{O}_{2}{ }^{44}\left[\left(\mathrm{CH}_{3}\right) \mathrm{N}(\mathrm{n}\right.$ $\left.\left.\mathrm{C}_{8} \mathrm{H}_{17}\right)_{3}\right]_{2} \mathrm{Mo}_{2} \mathrm{O}_{11}$ and $\left[\left(\mathrm{CH}_{3}\right) \mathrm{N}\left(\mathrm{n}-\mathrm{C}_{8} \mathrm{H}_{17}\right)_{3}\right]_{2} \mathrm{~W}_{2} \mathrm{O}_{11}$ with $\mathrm{H}_{2} \mathrm{O}_{2}$, ${ }^{45}$ $\left(\left[\mathrm{C}_{4} \mathrm{mim}\right] \mathrm{Cl} / 2 \mathrm{ZnCl}_{2}\right.$ and $\left.\left[\mathrm{C}_{4} \mathrm{mim}\right] \mathrm{Cl} / \mathrm{ZnCl}_{2}\right)$, $\left[\mathrm{CH}_{2} \mathrm{COOHmim}\right]\left[\mathrm{HSO}_{4}\right], \quad\left[\mathrm{SO}_{3} \mathrm{H}-\mathrm{C}_{4} \mathrm{mim}\right]\left[\mathrm{HSO}_{4}\right], \quad[\mathrm{Hmim}]\left[\mathrm{HSO}_{4}\right]$ and $\left[\mathrm{C}_{4}\right.$ mim] $\left[\mathrm{HSO}_{4}\right]$ with $\mathrm{H}_{2} \mathrm{O}_{2}$. ${ }^{46}$

We have recently reported diorganobismuth(III) halides of the type $\left[\mathrm{RCH}_{2} \mathrm{~N}\left(\mathrm{CH}_{2} \mathrm{C}_{6} \mathrm{H}_{4}\right)_{2}\right] \mathrm{BiX}\left(\mathrm{R}=\mathrm{C}_{6} \mathrm{H}_{5}, \mathrm{C}_{6} \mathrm{H}_{5} \mathrm{CH}_{2}, \mathrm{CH}_{3} \mathrm{OCH}, \mathrm{X}\right.$ = halogen $).{ }^{47} \mathrm{As}$ a continuation of our studies regarding the compounds based on a tetrahydrodibenzo[c,f][1,5]azabismocine heterocyclic framework we used the bromides $\left.\mathrm{RCH}_{2} \mathrm{~N}\left(\mathrm{CH}_{2} \mathrm{C}_{6} \mathrm{H}_{4}\right)_{2}\right] \mathrm{BiBr}[\mathrm{R}=$ $\mathrm{C}_{6} \mathrm{H}_{5}$ (1), $\mathrm{C}_{6} \mathrm{H}_{5} \mathrm{CH}_{2}$ (2)] to prepare the new species $\left[\mathrm{RCH}_{2} \mathrm{~N}\left(\mathrm{CH}_{2} \mathrm{C}_{6} \mathrm{H}_{4}\right)_{2}\right] \mathrm{BiX}\left[\mathrm{R}=\mathrm{C}_{6} \mathrm{H}_{5}, \mathrm{X}=\mathrm{ONO}_{2}(3), \mathrm{OSO}_{2} \mathrm{CF}_{3}(4)\right.$, $\mathrm{OSO}_{2} \mathrm{C}_{6} \mathrm{H}_{4}\left(\mathrm{CHCH}_{2}\right)-4$ (5); $\mathrm{R}=\mathrm{C}_{6} \mathrm{H}_{5} \mathrm{CH}_{2}, \quad \mathrm{X}=\mathrm{ONO}_{2}$ (6)]. Compounds $\mathbf{1}-\mathbf{6}$ were investigated as catalysts in the oxidation with air of thiophenol to diphenyl disulfide in both cyclohexane and IL (1-butyl-1-methylpyrrolidinium bis(trifluoromethanesulfonyl)imide).
Table 1. Performances of catalysts reported for the oxidation of thiols.

\begin{tabular}{|c|c|c|c|c|}
\hline Entry & Catalysts & $\begin{array}{l}\text { Yiel } \\
\text { d, \% }\end{array}$ & TON & Source \\
\hline 1 & $\mathrm{Al}_{2} \mathrm{O}_{3}$ & 99 & 0.02 & $\begin{array}{l}\text { RSC Adv., 2013, } \\
\text { 3, } 10680 .\end{array}$ \\
\hline \multirow[t]{2}{*}{2} & $\begin{array}{l}\text { Silica } \\
\text { Supported iron oxide }\end{array}$ & 95 & 8.2 & $\begin{array}{l}\text { RSC Adv., 2016, } \\
\text { 6, } 95753 .\end{array}$ \\
\hline & $\mathrm{NiO} / \mathrm{SiO}_{2}$ nanocluster & 99 & 198 & $\begin{array}{l}\text { Trans. Mat. Res. } \\
\text { Soc. Japan 2012, } \\
\text { 37, } 177 .\end{array}$ \\
\hline \multirow[t]{2}{*}{3} & Graphite oxide & 100 & 0.3 & $\begin{array}{l}\text { Org. Biomol. } \\
\text { Chem., 2011, 9, } \\
\text { 7292. }\end{array}$ \\
\hline & Cul & 90 & 0.09 & $\begin{array}{l}\text { RSC Adv., 2013, } \\
\text { 3, } 21369 .\end{array}$ \\
\hline 4 & $\mathrm{Fe}(\mathrm{III}) / \mathrm{Nal}$ & 100 & 10 & $\begin{array}{l}\text { Synthesis 1999, } \\
\mathbf{1}, 49 .\end{array}$ \\
\hline 5 & $\begin{array}{l}\text { Cobalt-iron magnetic } \\
\text { composites (Co0.5\%) }\end{array}$ & 100 & 2360 & $\begin{array}{l}\text { Appl. Catal., A } \\
2011,392,151 .\end{array}$ \\
\hline 6 & $\begin{array}{l}\mathrm{Fe}(\mathrm{BTC}) \quad \mathrm{BTC}: 1,3,5- \\
\text { benzenetricarboxylate }\end{array}$ & 98 & 6.7 & $\begin{array}{l}\text { Chem. } \\
\text { Commun., 2010, } \\
46,6476 \text {. }\end{array}$ \\
\hline \multirow[t]{4}{*}{7} & $\mathrm{Fe}(\mathrm{BTC})$ & 97 & 5.7 & Chem. \\
\hline & $\mathrm{Cu}_{3}(\mathrm{BTC})_{2}$ & 27 & 1.2 & Commun., 2012, \\
\hline & $\mathrm{Al}(\mathrm{OH})(\mathrm{BDC})$ & 4 & 0.18 & 48,11275 \\
\hline & $\mathrm{Fe}\left(\mathrm{NO}_{3}\right)_{3} \cdot 9 \mathrm{H}_{2} \mathrm{O}$ & 56 & 3.1 & \\
\hline 8 & 1,3,2-oxazaphosphole & 94 & 86 & $\begin{array}{l}\text { RSC Adv., 2015, } \\
\mathbf{5 , 4 5 9 8 3 .}\end{array}$ \\
\hline 9 & Diazenecarboxamide & 100 & 2 & $\begin{array}{l}\text { J. Chem. Soc., } \\
\text { Perkin Trans. 1, } \\
1998,3917 .\end{array}$ \\
\hline 10 & $\begin{array}{l}\text { Manganese(III) Schiff- } \\
\text { base complex }\end{array}$ & 98 & 20 & $\begin{array}{l}\text { Catal.Commun., } \\
2007,8,697 \text {. }\end{array}$ \\
\hline
\end{tabular}

\section{Results and discussion}

\section{Preparation and spectroscopic characterization}

Diorganobismuth(III) compounds of the general formula $\left[\mathrm{RCH}_{2} \mathrm{~N}\left(\mathrm{CH}_{2} \mathrm{C}_{6} \mathrm{H}_{4}\right)_{2}\right] \mathrm{BiX}\left[\mathrm{R}=\mathrm{C}_{6} \mathrm{H}_{5}, \mathrm{C}_{6} \mathrm{H}_{5} \mathrm{CH}_{2}, \mathrm{X}=\mathrm{ONO}_{2}, \mathrm{OSO}_{2} \mathrm{CF}_{3}\right.$, $\left.\mathrm{OSO}_{2} \mathrm{C}_{6} \mathrm{H}_{4}\left(\mathrm{CHCH}_{2}\right)-4\right]$ based on a butterfly-like tetrahydrodibenzo[c,f][1,5]azabismocine heterocyclic framework were prepared by ligand exchange reactions between the diorganobismuth(III) bromides $\mathbf{1}$ and $\mathbf{2}$ and the appropriate silver salt in a 1:1 molar ratio, as depicted in Scheme 1.

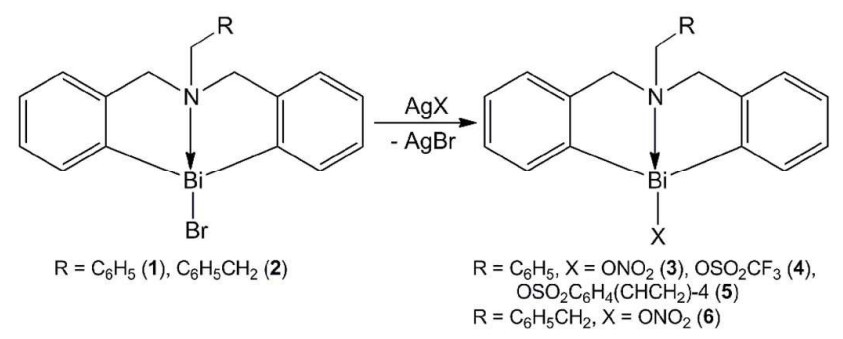

Scheme 1. Synthesis of diorganoBi(III) complexes $3-6$.

The bismuth(III) compounds $\mathbf{3} \mathbf{- 6}$ are microcrystalline solids, soluble in common organic solvents. The ${ }^{1} \mathrm{H},{ }^{13} \mathrm{C}\{\mathrm{H}\}$ and ${ }^{19} \mathrm{~F}\{\mathrm{H}\}$ NMR spectra are consistent with the presence of only one species in solution. The non-equivalent $\mathrm{CH}_{2} \mathrm{NCH}_{2}$ protons in the heterocyclic skeleton appear as an $A B$ spin system in the 
${ }^{1} \mathrm{H}$ NMR spectra, similarly with the situation found for the starting diorganobismuth(III) bromides 1 and $2 .{ }^{47}$

The IR spectra of the compounds $\mathbf{3}$ and $\mathbf{6}$ show strong, broad bands around $1445 \mathrm{~cm}^{-1}$, characteristic for the $v_{\text {as }}\left(\mathrm{NO}_{2}\right)$ stretching vibration, ${ }^{48}$ thus suggesting an unisobidentate coordination of the anionic $\mathrm{NO}_{3}{ }^{-}$ligand, while the spectra of the compounds $\mathbf{4}$ and $\mathbf{5}$ show strong bands in the ranges 1240-1295, 1160-1170 and 1010-1020 cm $\mathrm{cm}^{-1}$, which were assigned to the $\mathrm{vas}_{\mathrm{as}}\left(\mathrm{SO}_{2}\right), \mathrm{v}_{\mathrm{s}}\left(\mathrm{SO}_{2}\right)$ and $\mathrm{v}(\mathrm{SO})$ vibrations, respectively. ${ }^{49}$

\section{Single-crystal X-ray diffraction studies}

Compounds $\mathbf{3}-\mathbf{6}$ have similar molecular structures, with respect to the diorganobismuth(III) fragment, excepting that the crystal of $\mathbf{3}$ contains two independent molecules ( $\mathbf{3 a}$ and 3b) in the asymmetric unit. Several differences appear in the coordination behavior of the oxo-ligands and in the types of intermolecular associations evidenced in the crystal structures. Thermal ellipsoids representations of the molecular structures of $[3]_{2},[4]_{2}, 5$ and $[6]_{2}$ are depicted in Fig. $1-4$. Relevant interatomic distances and bond angles for the new compounds $\mathbf{3}-\mathbf{6}$, as well as for the starting bromides $\mathbf{1}$ and $\mathbf{2}^{\mathbf{4 7}}$ are given in the supporting information (see ESI, Table S1).

Strong transannular $\mathrm{N} \rightarrow \mathrm{Bi}$ interactions (range 2.402(3) 2.479(5) $\AA$, are found in compounds $3-6$ and they are of a similar magnitude with those observed in the related $\left[\mathrm{RN}\left(\mathrm{CH}_{2} \mathrm{C}_{6} \mathrm{H}_{4}\right)_{2}\right] \mathrm{BiX}\left(\mathrm{R}=\mathrm{Ph}, \mathrm{Cy} ; \mathrm{X}=\mathrm{Cl}, \mathrm{OC}(\mathrm{O}) \mathrm{CH}_{2} \mathrm{CH}_{2} \mathrm{GePh}_{3}\right.$, $\mathrm{BF}_{4}{ }^{50,51}{ }^{\mathrm{t}} \mathrm{BuN}\left(\mathrm{CH}_{2} \mathrm{C}_{6} \mathrm{H}_{4}\right)_{2} \mathrm{BiX}(\mathrm{X}=\text { halogen })^{34 \mathrm{~b}}$ or the starting diorganobismuth(III) bromides \{2.531(4) $\AA$ in $\left[\mathrm{C}_{6} \mathrm{H}_{5} \mathrm{CH}_{2} \mathrm{~N}\left(\mathrm{CH}_{2} \mathrm{C}_{6} \mathrm{H}_{4}\right)_{2}\right] \mathrm{BiBr} \quad(1)$ and 2.532(13) $\AA$ in $\left.\left[\mathrm{C}_{6} \mathrm{H}_{5} \mathrm{CH}_{2} \mathrm{CH}_{2} \mathrm{~N}\left(\mathrm{CH}_{2} \mathrm{C}_{6} \mathrm{H}_{4}\right)_{2}\right] \mathrm{BiBr}(2),{ }^{47}\right\}$, thus resulting in the formation of two five-membered $\mathrm{NC}_{3} \mathrm{Bi}$ rings in each case, respectively Bi1C1C6C7N1 (1) and Bi1C14C9C8N1 (2) in 3a and 4-6 and Bi2C22C27C28N3 (1) and Bi2C35C30C29N3 (2) in 3b. These rings are not planar, but folded along the imaginary $\mathrm{Bi} 1 \cdots \mathrm{C} 7$ and $\mathrm{Bi} 1 \cdots \mathrm{C} 8$ axes in $3 a$ and $4-6$ and about the imaginary $\mathrm{Bi} 2 \cdots \mathrm{C} 28$ and $\mathrm{Bi} 2 \cdots \mathrm{C} 29$ axes in $\mathbf{3 b}$.

Due to the planar chirality ${ }^{52}$ induced by the $\mathrm{N} \rightarrow \mathrm{Bi}$ intramolecular coordination, the compounds crystallize as $1: 1$ mixtures of $R^{1}, R^{2}$ and $S^{1}, S^{2}$ isomers (the superscript indices " 1 " and " 2 " refer to the two five-membered rings, as designated above).

In $\mathbf{3}$ and $\mathbf{6}$ the $\mathrm{NO}_{3}{ }^{-}$ligand is unisobidentate coordinated to bismuth, thus resulting in hypercoordinated $12-\mathrm{Bi}-5$ species. ${ }^{53}$ In both compounds the molecules are associated in dimers by bridging $\mathrm{NO}_{3}{ }^{-}$ligands which behave as bimetallic triconnective moieties in $\mathbf{3}$ (Fig. 1) and bimetallic tetraconnective moieties in 6 (Fig. 4).

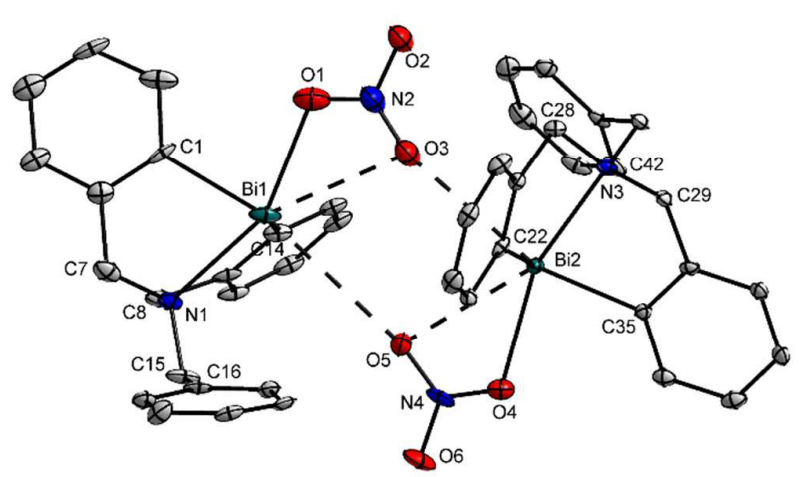

Fig. 1. Thermal ellipsoids representation at $30 \%$ probability in a dimer of $S^{1}, S^{2}-\mathbf{3 a}$ and $R^{1}, R^{2}-\mathbf{3 b}$ isomers (hydrogen atoms are omitted for clarity).

In $\mathbf{3 b}$ the benzyl group in the pendant arm is twisted in such a position that a $\mathrm{Bi} \cdots \pi$ arene interaction of $3.895 \AA$ between $\mathrm{Bi} 2$ and the phenyl ring of the pendant arm might also be considered. ${ }^{54}$

In compounds 4 and 5 the $\mathrm{CF}_{3} \mathrm{SO}_{3}{ }^{-}$and the $4-\left(\mathrm{CH}_{2} \mathrm{CH}\right) \mathrm{C}_{6} \mathrm{H}_{4} \mathrm{SO}_{3}{ }^{-}$ ligands, respectively, are monodentate coordinated to bismuth by oxygen and these compounds can be described as hypercoordinated 10-Bi-4 species with a distorted see-saw coordination geometry about bismuth [O1-Bi1-N1 147.27(13) in 4 and $144.79(14)^{\circ}$ in 5].

Strong $\mathrm{Bi} \cdots \pi$ arene interactions $\left[\mathrm{Bi} 1 \cdots \mathrm{Cg} 1{ }^{\prime}\left(\mathrm{C}{ }^{\prime}-\mathrm{C} 14{ }^{\prime}\right) 3.535 \AA\right.$ vs. $4.1 \AA$ were evidenced and the upper value reported for other bismuth compounds displaying such interactions ${ }^{54}$ results in dimeric associations in $\mathbf{4}$.

A closer look at the crystal packing of the four compounds revealed further intermolecular interactions, thus leading to supramolecular networks in compounds $\mathbf{3}-\mathbf{6}$. But only in compound $\mathbf{3}$ the bismuth atoms in the molecules $\mathbf{3 a}$ are involved in further associations of dimers by $\pi \mathrm{Bi1}$ … Cg1' interactions of $3.586 \AA$ (see ESI, Fig. S1), thus determining a more congested environment about the metal centre, while in the crystals of $\mathbf{4 - 6}$ only nonclassical hydrogen bonds, $\mathrm{O} \cdots \mathrm{H}$ or $\pi \mathrm{H} \cdots \mathrm{Cg}$ contacts, contribute to the supramolecular networks. 


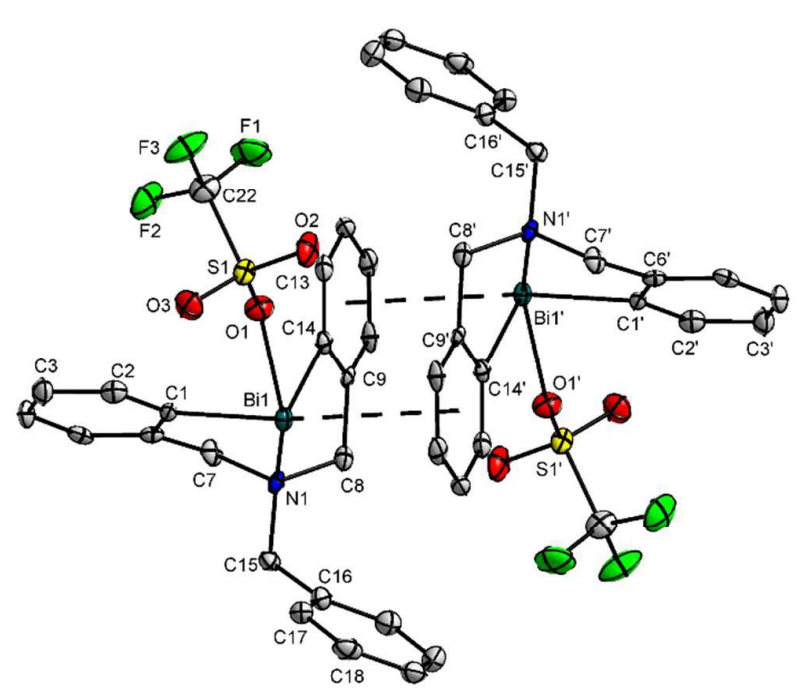

Fig. 2. Thermal ellipsoids representation at $50 \%$ probability and atom numbering scheme in a dimer of $S^{1}, S^{2}-4$ and $R^{1}, R^{2}-4$ isomers (hydrogen atoms are omitted for clarity). Symmetry equivalent position $1-x,-y, 1-z$ is given by "prime".

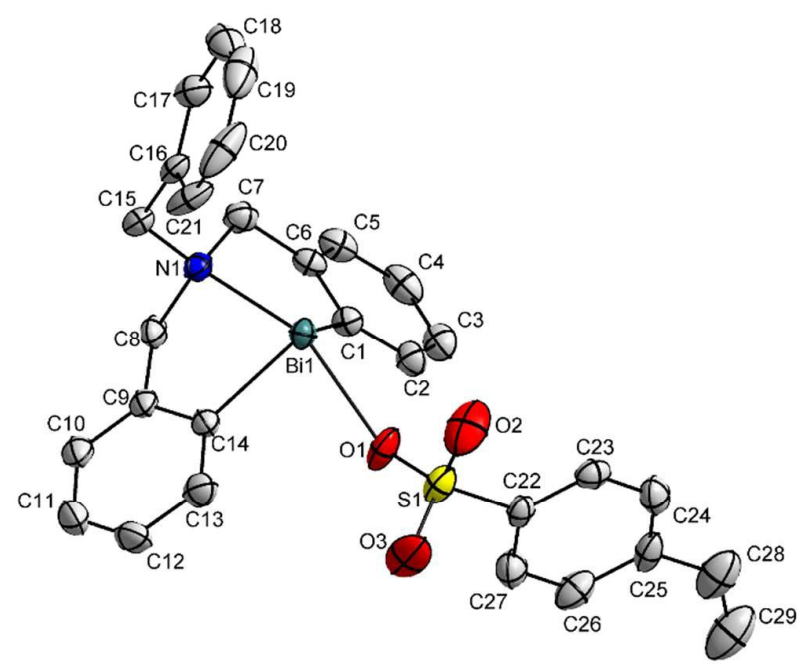

Fig. 3. Thermal ellipsoids representation at $30 \%$ probability and atom numbering scheme in $R^{1}, R^{2}-5$ isomer (hydrogen atoms are omitted for clarity).

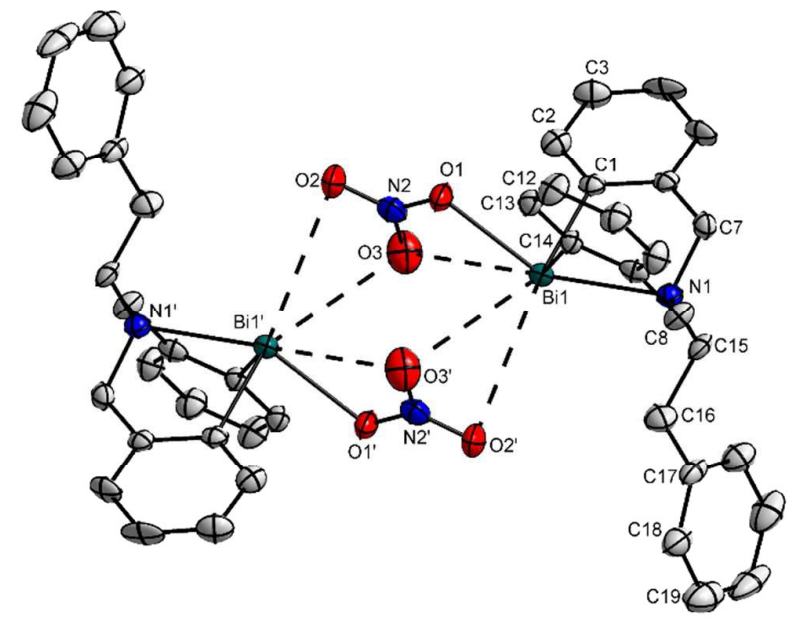

Fig. 4. Thermal ellipsoids representation at $30 \%$ probability and atom numbering scheme in a dimer of $R^{1}, R^{2}-6$ and $S^{1}, S^{2}-6$ isomers (hydrogen atoms are omitted for clarity). Symmetry equivalent position $-x,-y,-z$ is given by "prime".

\section{Catalytic behavior}

In the absence of the catalyst some air oxidation of thiophenol to diphenyl disulfide (Scheme 2) occurred albeit with a low conversion (below $6 \%$ after $5 \mathrm{~h}$ ), as can be seen from Fig. 5, irrespective of the solvent nature (cyclohexane or IL). This is in agreement with previous reports mentioning that in neutral media in which there are no radical initiators slow air oxidation occurs. ${ }^{55}$

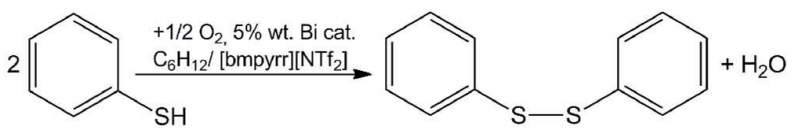

Scheme 2. Oxidative coupling of thiophenol to diphenyl disulfide.

Simple addition of $\mathrm{NaOH}$ led to an increase in the conversion to $16 \%$ after $5 \mathrm{~h}$, which might be explained by the fact that the autooxidation of thiols to disulfides, proceeding via the thyil radical $(|\mathrm{RS}|)$ and ${ }^{-} \mathrm{O}-\mathrm{O}^{-}$species, is enhanced in the presence of an excess of base. ${ }^{55}$

In the presence of the diorganobismuth(III) bromides $\left[\mathrm{RCH}_{2} \mathrm{~N}\left(\mathrm{CH}_{2} \mathrm{C}_{6} \mathrm{H}_{4}\right)_{2}\right] \mathrm{BiBr}$ a further increase of the catalytic activity was observed, thus reaching a conversion of $21 \%$ for $\mathrm{R}=\mathrm{C}_{6} \mathrm{H}_{5}$ (1) and more than double (51\%) for $\mathrm{R}=\mathrm{C}_{6} \mathrm{H}_{5} \mathrm{CH}_{2}$ (2), corresponding to TON values of 7.3 and 17.8 , respectively. These different behaviors might be explained by the observation that in solid state the bismuth atom in 1 is involved in weak $\mathrm{Bi} \cdots \mathrm{Br}(4.227 \AA$ A ) and $\mathrm{Bi} \cdots \pi$ arene $(4.097 \AA)$ intermolecular interactions (see ESI, Fig. S2), whilst in 2 the $\mathrm{Bi}$ is not involved in any intra- or intermolecular interactions, except the transannular $\mathrm{N} \rightarrow \mathrm{Bi}$ one (see ESI, Fig. S3). The latter is present in both $\mathbf{1}$ and $\mathbf{2}$ and of a similar magnitude [2.531(4) Å in 1 and 2.532(13) A in 2]. ${ }^{47}$

Therefore, it is likely to be a significant difference in the accessibility of the active site for the organic substrates to bind. Furthermore, the activity of the diorganobismuth(III) compounds $\mathbf{3}$ 6 resulted in high conversions and TON. 


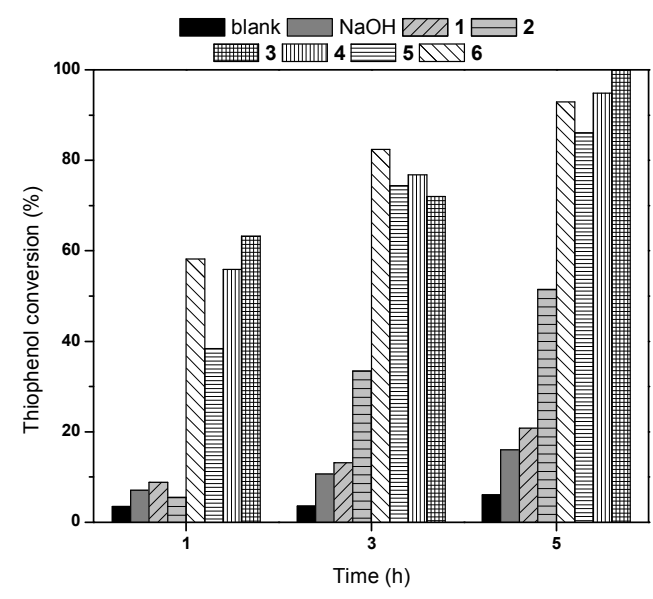

Fig. 5. The activity of the heterocyclic bismuth(III) compounds $\mathbf{1}-\mathbf{6}$ (the experiments were performed in cyclohexane).

After $5 \mathrm{~h}$ the conversions $(\%) /$ TONs obtained were in the following order $3(100 / 34.8)>4(94.8 / 33.0)>6(92.9 / 32.4)>5$ (86.1/30.0).

Table 2 compiles activity results of the compound $\mathbf{4}$ for the oxidation of various thiols.

Table 2. The oxidative coupling of several thiols to disulfides using compound 4.

\begin{tabular}{llcll}
\hline Entry & Thiols & Conv. (\%) & Sel. (\%) & TON \\
\hline 1 & Thiophenol & 94.8 & 100 & 33 \\
2 & 4-Methylbenzenethiol & 100 & 100 & 35 \\
3 & 1-Butanethiol & 100 & 100 & 35 \\
4 & 1-Octanethiol & 66.4 & 100 & 23 \\
\hline
\end{tabular}

The relative activity of these molecular catalysts should be associated to the polarizability of bismuth in the presence of different $\mathrm{X}^{-}$ligands and with the Lewis acidity (Bi) / basicity $(\mathrm{N})$ of the catalytic species.

DFT calculations revealed the variation of the positive charge on bismuth (q-Bi, Table 3) in the order $5>\mathbf{4}>\mathbf{3}>\mathbf{1}$, while the negative charge on nitrogen varies in the order $\mathbf{4}>\mathbf{5}>\mathbf{3}>\mathbf{1}(\mathrm{q}-\mathrm{N}$, Table 3). The latter sequence is correlated with the experimentally determined $\mathrm{N} \rightarrow \mathrm{Bi}$ distances $(\mathbf{4}<\mathbf{5}<\mathbf{3}<\mathbf{1})$.

Anyway, the $\mathrm{N} \rightarrow \mathrm{Bi}$ interatomic distances in compounds $3-6$ are of a similar magnitude, but shorter than in the bromides $\mathbf{1}$ and 2. This behaviour correlates well with the variation of the charge calculated for nitrogen and with the variation of the Hammett's constant for the substituents attached to bismuth, which is a measure of the electronic effects and the polarizability of the $\mathrm{Bi}$-ligand bond (Table 3). ${ }^{56}$

As a consequence, the increased catalytic activity of the complexes with oxygenated ligands in comparison with the diorganobismuth bromides is explained by the lower polar character of the $\mathrm{Bi}-\mathrm{Br}$ bonds in comparison with the $\mathrm{Bi}-\mathrm{O}$ bonds. In addition, the differences in the catalytic behavior of the complexes 3 - 6 might be determined by the secondary interactions in the coordination sphere of bismuth and their influence on both the polarizability of the metal-ligand bond and the accessibility of the organic substrate.

Table 3. $\mathrm{N} \rightarrow \mathrm{Bi}$ transannular interactions $(\AA)$, Hammett's constants* and calculated charge on $\mathrm{Bi}$ and $\mathrm{N}$ in compounds $\mathbf{1}$ and $\mathbf{3}-\mathbf{5}$.

\begin{tabular}{lllll}
\hline & $\mathbf{1}$ & $\mathbf{3}$ & $\mathbf{4}$ & $\mathbf{5}$ \\
\hline $\mathrm{N} \rightarrow \mathrm{Bi}$ & $2.531(4)$ & $2.473(8)$ & $2.402(3)$ & $2.454(4)$ \\
& & $2.453(7)$ & & \\
Hammett's constant, $\sigma^{56 a}$ & 0.39 & 0.55 & 0.56 & - \\
$\mathrm{q}-\mathrm{Bi}$ & 0.790 & 0.915 & 0.925 & 0.929 \\
$\mathrm{q}-\mathrm{N}$ & -0.240 & -0.239 & -0.232 & -0.237 \\
\hline
\end{tabular}

* Hammett's constants for compounds 1, 3 and $\mathbf{4}$ are given as previously reported in ref. $56 \mathrm{a}$ for $\mathrm{Br}, \mathrm{ONO}_{2}$ and $\mathrm{CF}_{3} \mathrm{SO}_{3}$.

In case of compounds $\mathbf{3}$ and $\mathbf{6}$ it seems that the length of the aliphatic chain in the organic group attached to nitrogen does not influence the catalytic behaviour by itself, but it is responsible for the structural differences in the two compounds in solid state.

Changing the molecular solvent from cyclohexane to 1-butyl-1methylpyrrolidinium bis(trifluoromethanesulfonyl)imide) lead to an increase of the catalytic activity (Fig. 6).

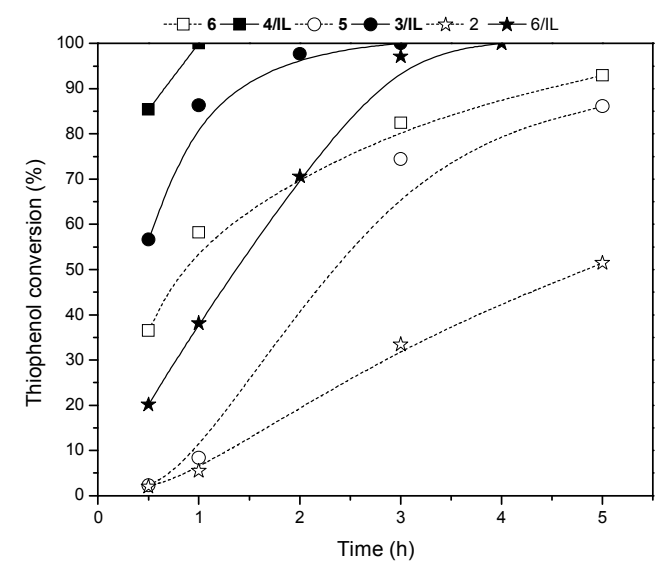

Fig. 6. Time evolution of the conversion of thiophenol to disulfide in the presence of 2, 5 and $\mathbf{6}$ as catalysts. The experiments were performed in cyclohexane (open element) and 1-butyl-1-methylpyrrolidinium bis(trifluoromethanesulfonyl)imide (close element).

It can be observed that complete conversion was reached for catalyst $\mathbf{6}$ in approx. $1 \mathrm{~h}$. It is noteworthy that this change in solvent did not affect the final selectivity to diphenyl disulfide. This increase in activity is thought to be due to the increased solubility of the molecular oxygen in the ionic liquid compared with the cyclohexane, as well as to the complete ionization of the catalyst in solution. ${ }^{57}$

These experiments clearly demonstrate the positive influence of the IL as solvent. Moreover, the use of IL allowed a good recycling of the catalysts with only a small decrease in conversion from 92.9 to $85.8 \%$ for catalyst $\mathbf{4}$ over two consecutive reactions. This is in good agreement with previous reports on the stabilizing capacity of ILs in various catalytic reactions. ${ }^{58}$ 
Literature reported several mechanisms for this reaction. Based on EPR measurements Corma et al. concluded that on oxide heterogeneous catalysts the reaction is controlled by a radical pathway implying a homolytic $\mathrm{S}-\mathrm{H}$ scission from the original thiol. ${ }^{59}$ The same conclusion has been drawn by Garcia et al for MOF-type catalysts. ${ }^{60} \mathrm{~A}$ radical mechanism has also been proposed using inorganic complexes. ${ }^{61,62}$

Taking into account the experimental data collected in this study, a reaction pathway based on a two steps addition of $\mathrm{PhSH}$ to bismuth might be proposed (Fig. 7). In the first step it is formed a pentacoordinated $\mathrm{Bi}(\mathrm{III})$ species, with a trigonal bipyramidal coordination geometry, while the addition of the second $\mathrm{PhSH}$ molecule resulted in an octahedral $\mathrm{Bi}(\mathrm{III})$ species. We assume that the $\mathrm{ONO}_{2}$ ligand acts as a monodentate moiety in the phenylthiolato bismuth(III) intermediates. In order to bring evidences for the proposed mechanism we performed a NMR tube scale reaction and we studied the in situ solution behavior of a mixture of compound 6 and thiophenol (1:2 molar ratio, in toluene- $d_{8}$ ) by a combination of ${ }^{1} \mathrm{H}$ NMR and MS experiments.

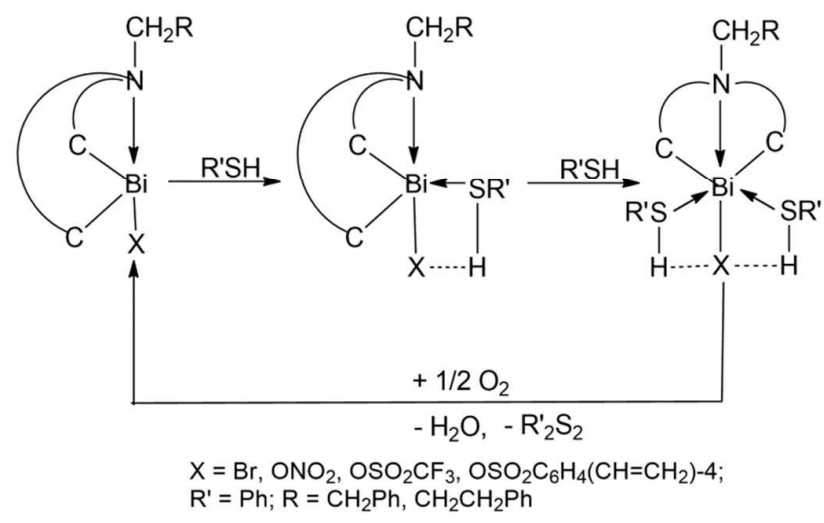

Fig. 7. Possible reaction pathway for the oxidation of thiophenol to diphenyl disulfide.

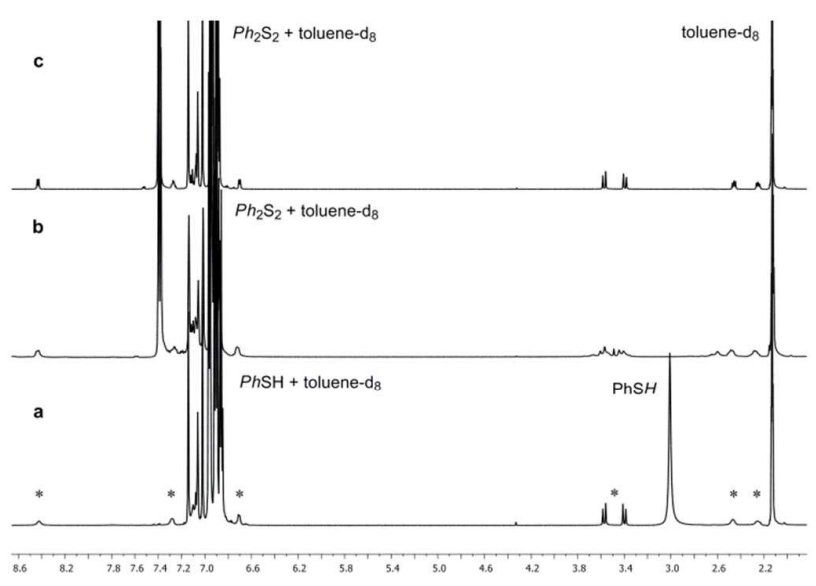

Fig. 8. ${ }^{1} \mathrm{H}$ NMR spectra (toluene- $\mathrm{d}_{8}$ ) of a reaction mixture of $\mathrm{PhSH}$ and compound $6\left(^{*}\right)$ showing the formation of $\mathrm{Ph}_{2} \mathrm{~S}_{2}:$ (a) during the first 2 hours, at $20{ }^{\circ} \mathrm{C}$.; (b) the solution behaviour at $80^{\circ} \mathrm{C}$; (c) a mixture of pure $\mathrm{Ph}_{2} \mathrm{~S}_{2}$ and 6.

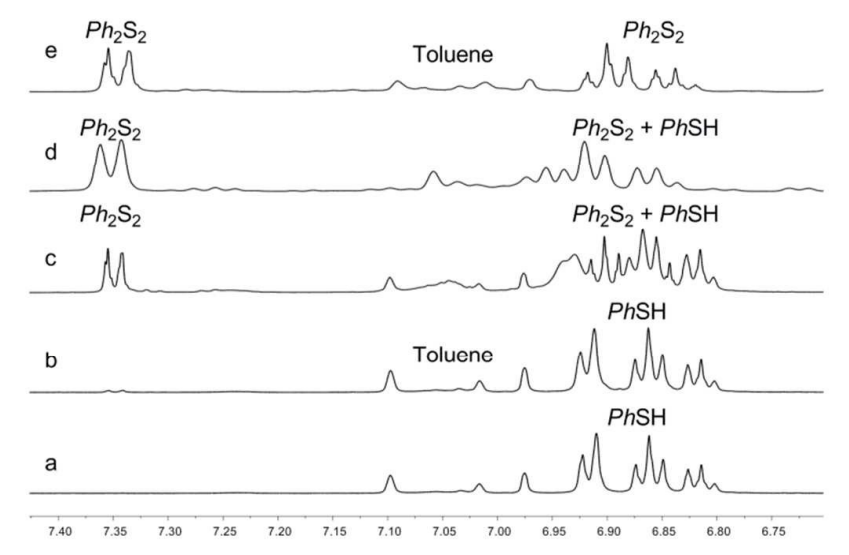

Fig. 9. Detail of the aromatic region in the ${ }^{1} \mathrm{H}$ NMR spectra of a mixture of $\mathrm{PhSH}$ and compound 6, showing the formation of $\mathrm{Ph}_{2} \mathrm{~S}_{2}$. (a) immediately after adding the solvent, at $20^{\circ} \mathrm{C}$, (b) after 2 hours at $20^{\circ} \mathrm{C}$, (c) after 24 hours at $20^{\circ} \mathrm{C},(\mathrm{d})$ at $80^{\circ} \mathrm{C}$, (e) again at $20^{\circ} \mathrm{C}$. Spectra a - c are recorded on a $600 \mathrm{MHz}$ NMR spectrometer, while spectra d and e on a $400 \mathrm{MHz} \mathrm{NMR}$ spectrometer.

At room temperature the ${ }^{1} \mathrm{H}$ NMR spectrum suggested that only about $10 \%$ of the catalyst 6 has been solubilized (Fig. 8). During the first $2 \mathrm{~h}$, it showed no change of the mixture (Figure 9, and ESI, Fig. S4), when only characteristic resonances for the pure PhSH and 6 were found in the spectrum. However, the solution turned to slightly yellow, thus indicating the formation of some bismuth organothiolates. ${ }^{63}$ Also, after $2 \mathrm{~h}$, the ESI+ mass spectrum of the solution has shown a peak of very low intensity (1\%) at $\mathrm{m} / \mathrm{z} 618.17$, thus suggesting the formation of the species $\left[\left\{\mathrm{C}_{6} \mathrm{H}_{5} \mathrm{CH}_{2} \mathrm{CH}_{2} \mathrm{~N}\left(\mathrm{CH}_{2} \mathrm{C}_{6} \mathrm{H}_{4}\right)_{2}\right\} \mathrm{BiSPh}^{+}\right]$. The base peak at $\mathrm{m} / \mathrm{z} 508.15$ corresponds to the cation $\left[\left\{\mathrm{C}_{6} \mathrm{H}_{5} \mathrm{CH}_{2} \mathrm{CH}_{2} \mathrm{~N}\left(\mathrm{CH}_{2} \mathrm{C}_{6} \mathrm{H}_{4}\right)_{2}\right\} \mathrm{Bi}^{+}\right]$(see ESI, Fig. S7). After $24 \mathrm{~h}$ the intensity of the peak at $\mathrm{m} / \mathrm{z} 618.17$ increased to about $20 \%$, while the ${ }^{1} \mathrm{H}$ NMR spectrum has shown the decrease in intensity of the resonance corresponding to the $\mathrm{PhSH}$ proton in the alifatic region and the formation of $\mathrm{Ph}_{2} \mathrm{~S}_{2}$ (see ESI, Figs. S4 - S6). We noticed that the $\mathrm{C}_{6} \mathrm{H}_{5}$-ortho protons in $\mathrm{Ph}_{2} \mathrm{~S}_{2}$ are strongly shifted at lower field in comparison with those in $\mathrm{PhSH}$. The increase of the temperature up to $80^{\circ} \mathrm{C}$ has been accompanied by several changes in the spectrum of the bismuth(III) complex, but in the range $20-$ $80{ }^{\circ} \mathrm{C}$ the resonance associated to the $\mathrm{CH}_{2} \mathrm{NCH}_{2}$ protons appears as an $A B$ spin system, thus suggesting that nitrogen remains coordinated to bismuth. However, $\mathrm{Ph}_{2} \mathrm{~S}_{2}$ has been detected only with a low intensity in the ESI+ mass spectrum, due to the poor ionization. To improve the ionization capacity of this species, we changed to $\mathrm{APCl}+$, when a peak corresponding to $\left[\mathrm{Ph}_{2} \mathrm{~S}_{2}^{+}\right]$appeared at $\mathrm{m} / \mathrm{z} 218.02$ (43\%), along with the cation at $\mathrm{m} / \mathrm{z} 508.15$ (see ESI, Fig. S8). At this point, the ${ }^{1} \mathrm{H}$ NMR spectrum of the final solution suggests the existence of at least two bismuth containing species, but unambiguously could be identified only the starting compound 6. To identify the nature of the insoluble species we added $5 \mathrm{~mL}$ of toluene and we heated the mixture at reflux $\left(110^{\circ} \mathrm{C}\right)$ for $15 \mathrm{~min}$., with stirring, when the solution became clear. Then, decreasing again the temperature to $20{ }^{\circ} \mathrm{C}$, the colourless precipitate was formed again and it has been identified by ${ }^{1} \mathrm{H}$ NMR as the starting catalyst 6 . The $\mathrm{APCl}+\mathrm{MS}$ spectrum of the final solution shows a 
peak at $\mathrm{m} / \mathrm{z} 427.14(52 \%)$, corresponding to the cation $\left[(\mathrm{PhS})_{2} \mathrm{Bi}^{+}\right]$ (Fig. S9), which might suggest the formation of an intermediate containing two phenylthiolato groups attached to the bismuth complex, thus confirming the pathway described in Fig. 7. This is also in line with the previous reports considering a radical mechanism. ${ }^{59-61}$

Up to $70^{\circ} \mathrm{C}$ no NMR resonance characteristic for water formation has been observed. We attribute this fact to its physical adsorption on the remained solid catalyst, which only at higher temperature is desorbed (see ESI, Fig. S6).

The IR spectra of the pure compounds 4 and 6 show no significant differences of the bands assigned to the Bi complex in comparison with the solid separated after the oxidation of thiophenol in cyclohexane. We could only notice the formation of $\mathrm{Ph}_{2} \mathrm{~S}_{2}$ and water (see ESI, Fig. S10).

\section{Experimental}

\section{General}

Organic solvents were dried and distilled prior to use. The ionic liquid, 1-butyl-1-methylpyrrolidinium bis(trifluoromethanesulfonyl) imide, was prepared following standard procedures. ${ }^{64}$ Initial, 1butyl-1-methylpyrrolidinium bromide $[\mathrm{Bmpyrr}][\mathrm{Br}]$ was synthesized by mixing 1-methylpyrrolidine (200 mmoles) in acetone $(75 \mathrm{~mL})$ with equal molar amounts of 1-bromobutane in a round-bottomed flask. The reaction flask was immediately covered with aluminum foil. The mixture was stirred for 2 days until a white semi-solid was formed. The obtained solid was washed with cold acetone and separated by filtration. The anion exchange was performed further by using lithium bis(trifluoromethanesulfonimide) $\left[\mathrm{LiN}\left(\mathrm{CF}_{3} \mathrm{SO}_{2}\right)_{2}\right]$. An aqueous solution of $\mathrm{LiN}\left(\mathrm{CF}_{3} \mathrm{SO}_{2}\right)$ (slight excess) was mixed with an aqueous solution of $[\mathrm{Bmpyrr}][\mathrm{Br}]$ for $2 \mathrm{~h}$. The obtained ionic liquid [Bmpyrr] $\left[\mathrm{NTf}_{2}\right]$ was extracted from the aqueous phase three times with dichloromethane. The solvent was removed using a rotary evaporator at $60{ }^{\circ} \mathrm{C}$ and the ionic liquid was dried for $24 \mathrm{~h}$ under high vacuum.

Experiments involving air sensitive compounds were carried out under argon atmosphere. Elemental analyses were performed on a Flash EA 1112 analyzer. Melting points were measured on an Electrothermal 9200 apparatus and are not corrected. ${ }^{1} \mathrm{H},{ }^{13} \mathrm{C}\{\mathrm{H}\}$ and ${ }^{19} \mathrm{~F}\{\mathrm{H}\}$ NMR spectra for compounds $\mathbf{3}-\mathbf{6}$ were recorded in $\mathrm{CDCl}_{3}$ on a Bruker 500 equipment, while the NMR spectra of the reaction mixture of $\mathrm{PhSH}$ and 6 were recorded at room temperature on a Bruker 600 and at higher temperature on a Bruker 400 equipment. The NMR spectra were processed with the MestReNova software. ${ }^{65}$ The chemical shifts are reported in $\delta$ units (ppm) relative to TMS $\left({ }^{1} \mathrm{H}\right.$ and $\left.{ }^{13} \mathrm{C}\right)$ and $\mathrm{CFCl}_{3}\left({ }^{19} \mathrm{~F}\right)$. The ${ }^{1} \mathrm{H}$ and ${ }^{13} \mathrm{C}$ chemical shifts were assigned based on 2D NMR experiments and they are given according to the numbering in Scheme 3. ESI+ and $\mathrm{APCl}+$ mass spectra were recorded in $\mathrm{CH}_{3} \mathrm{CN}$ on a LTQ Orbitrap - XL instrument. The IR spectra were recorded in the range $4000-400$ $\mathrm{cm}^{-1}$ on a Jasco spectrometer. Starting materials were commercially available or were prepared according to literature procedures, $\left[\mathrm{C}_{6} \mathrm{H}_{5} \mathrm{CH}_{2} \mathrm{~N}\left(\mathrm{CH}_{2} \mathrm{C}_{6} \mathrm{H}_{4}\right)_{2}\right] \mathrm{BiBr}$ (1) and $\left[\mathrm{C}_{6} \mathrm{H}_{5} \mathrm{CH}_{2} \mathrm{CH}_{2} \mathrm{~N}\left(\mathrm{CH}_{2} \mathrm{C}_{6} \mathrm{H}_{4}\right)_{2}\right] \mathrm{BiBr}$ (2). ${ }^{47}$ The synthesis of silver 4-vinylbenzenesulfonate is given in the electronic supporting information.

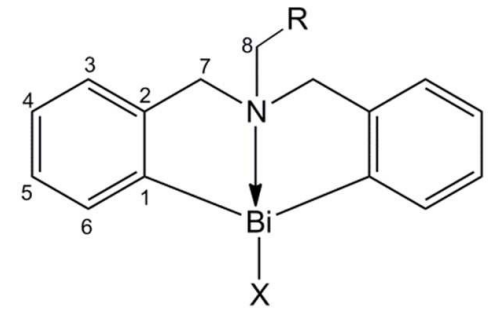

Scheme 3.

\section{Synthesis of $\left[\mathrm{C}_{6} \mathrm{H}_{5} \mathrm{CH}_{2} \mathrm{~N}\left(\mathrm{CH}_{2} \mathrm{C}_{6} \mathrm{H}_{4}\right)_{2}\right] \mathrm{BiONO}_{2}$ (3)}

A mixture of $\left[\mathrm{C}_{6} \mathrm{H}_{5} \mathrm{CH}_{2} \mathrm{~N}\left(\mathrm{CH}_{2} \mathrm{C}_{6} \mathrm{H}_{4}\right)_{2}\right] \mathrm{BiBr}(0.143 \mathrm{~g}, 0.249 \mathrm{mmol})$ and $\mathrm{AgNO}_{3}(0.05 \mathrm{~g}, 0.294 \mathrm{mmol})$ in acetone $(20 \mathrm{~mL})$, was left under stirring, in the absence of light, for $2 \mathrm{~h}$. The solvent was removed in vacuum and the remained solid was treated with $\mathrm{CH}_{2} \mathrm{Cl}_{2}(20 \mathrm{~mL})$. $\mathrm{AgBr}$ was removed by filtration and from the clear solution, after the removal of the solvent, the title compound was isolated as a colorless solid. Yield: 0.155 g (93\%). M.p. $151{ }^{\circ} \mathrm{C}$ (dec.). Anal. Calcd. for $\mathrm{C}_{21} \mathrm{H}_{19} \mathrm{BiN}_{2} \mathrm{O}_{3}$ (MW = 556.37): $\mathrm{C} 45.33, \mathrm{H}$ 3.44, N 5.04; Found $\mathrm{C}$ 45.51, $\mathrm{H}$ 3.58, N 5.13. ${ }^{1} \mathrm{H}$ NMR $\left(\mathrm{CDCl}_{3}, 500 \mathrm{MHz}\right): \delta 4.08\left(\mathrm{~s}, 2 \mathrm{H}, \mathrm{H}_{8}\right)$, 4.36 ( $\mathrm{AB}$ spin system with $\delta_{\mathrm{A}} 4.26$ and $\delta_{B} 4.47,4 \mathrm{H}, \mathrm{H}_{7},{ }^{2} \mathrm{~J}_{\mathrm{HH}} 14.4 \mathrm{~Hz}$ ), 7.30-7.32 (m, 2H, $\mathrm{C}_{6} \mathrm{H}_{5}$-ortho), $7.35\left(\mathrm{dt}, 2 \mathrm{H}, \mathrm{C}_{6} \mathrm{H}_{4}-\mathrm{H}_{4},{ }^{3} \mathrm{~J}_{\mathrm{HH}} 7.3,{ }^{4} \mathrm{~J}_{\mathrm{HH}} 1.3\right.$ $\mathrm{Hz}), 7.42-7.45\left(\mathrm{~m}, 3 \mathrm{H} \mathrm{C}_{6} \mathrm{H}_{5}-\right.$ meta+para) $7.53\left(\mathrm{~d}, 2 \mathrm{H} \mathrm{C}_{6} \mathrm{H}_{4}-\mathrm{H}_{5},{ }^{3} \mathrm{~J}_{\mathrm{HH}} 8.02\right.$ $\mathrm{Hz}), 7.56\left(\mathrm{t}, 2 \mathrm{H}, \mathrm{C}_{6} \mathrm{H}_{4}-\mathrm{H}_{3},{ }^{3} \mathrm{~J}_{\mathrm{HH}} 7.3 \mathrm{~Hz}\right), 8.22\left(\mathrm{~d}, 2 \mathrm{H}, \mathrm{C}_{6} \mathrm{H}_{4}-\mathrm{H}_{6},{ }^{3} \mathrm{~J}_{\mathrm{HH}} 7.1\right.$ $\mathrm{Hz}) .{ }^{13} \mathrm{C}\{\mathrm{H}\} \mathrm{NMR}\left(\mathrm{CDCl}_{3}, 125.72 \mathrm{MHz}\right): \delta 60.45\left(C_{8}\right), 63.84\left(C_{7}\right)$, $128.67\left(C_{4}\right), 128.92\left(C_{3}\right), 129.44\left(C_{6} \mathrm{H}_{5}\right.$-meta $), 129.75\left(C_{6} \mathrm{H}_{5}\right.$-para $)$, $131.16\left(\mathrm{C}_{6} \mathrm{H}_{5}\right.$-ortho $), 131.66\left(C_{5}\right), 133.11\left(\mathrm{C}_{6} \mathrm{H}_{5}\right.$-ipso $), 138.39\left(C_{6}\right)$, $148.97\left(C_{2}\right), 180.3\left(C_{1}\right) . \operatorname{IR}\left(\mathrm{v}, \mathrm{cm}^{-1}\right): 1453,1436$.

Compounds $4-6$ were prepared similarly.

\section{$\left[\mathrm{C}_{6} \mathrm{H}_{5} \mathrm{CH}_{2} \mathrm{~N}\left(\mathrm{CH}_{2} \mathrm{C}_{6} \mathrm{H}_{4}\right)_{2}\right] \mathrm{BiOSO}_{2} \mathrm{CF}_{3}(4)$}

From $\left[\mathrm{C}_{6} \mathrm{H}_{5} \mathrm{CH}_{2} \mathrm{~N}\left(\mathrm{CH}_{2} \mathrm{C}_{6} \mathrm{H}_{4}\right)_{2}\right] \mathrm{BiBr}(0.188 \mathrm{~g}, 0.327 \mathrm{mmol})$ and AgOTf $(0.089 \mathrm{~g}, 0.34 \mathrm{mmol})$ in acetone $(20 \mathrm{~mL})$, as a colorless solid. Yield: 0.210 g (94\%). M.p. $155{ }^{\circ} \mathrm{C}$ (dec.). Anal. Calcd. for $\mathrm{C}_{22} \mathrm{H}_{19} \mathrm{BiF}_{3} \mathrm{NO}_{3} \mathrm{~S}$ $(\mathrm{MW}=643.43): \mathrm{C} 41.07, \mathrm{H} 2.98, \mathrm{~N} 2.18 \%$. Found $\mathrm{C} 40.91, \mathrm{H} 2.77, \mathrm{~N}$ 2.09\%. ${ }^{1} \mathrm{H}$ NMR $\left(\mathrm{CDCl}_{3}, 500 \mathrm{MHz}\right): \delta 4.13\left(\mathrm{~s}, 2 \mathrm{H}, \mathrm{H}_{8}\right), 4.49$ (AB spin system with $\delta_{A} 4.39$ and $\left.\delta_{B} 4.59,4 \mathrm{H}, \mathrm{H}_{7},{ }^{2} \mathrm{~J}_{\mathrm{HH}} 14.5 \mathrm{~Hz}\right), 7.28-7.30(\mathrm{~m}$, $2 \mathrm{H}, \mathrm{C}_{6} \mathrm{H}_{5}$-ortho), 7.39 (dt, $2 \mathrm{H}, \mathrm{C}_{6} \mathrm{H}_{4}-\mathrm{H}_{4},{ }^{3} \mathrm{~J}_{\mathrm{HH}} 7.6,{ }^{4} \mathrm{~J}_{\mathrm{HH}} 1.4 \mathrm{~Hz}$ ), $7.44-$ $7.47\left(\mathrm{~m}, 3 \mathrm{H} \mathrm{C}_{6} \mathrm{H}_{5}\right.$-meta+para) $7.61\left(\mathrm{~d}, 2 \mathrm{H} \mathrm{C}_{6} \mathrm{H}_{4}-\mathrm{H}_{3},{ }^{3} \mathrm{~J}_{\mathrm{HH}} 7.7 \mathrm{~Hz}\right), 7.65$ $\left(\mathrm{t}, 2 \mathrm{H}, \mathrm{C}_{6} \mathrm{H}_{4}-\mathrm{H}_{5},{ }^{3} \mathrm{~J}_{\mathrm{HH}} 7.3 \mathrm{~Hz}\right), 8.39\left(\mathrm{~d}, 2 \mathrm{H}, \mathrm{C}_{6} \mathrm{H}_{4}-\mathrm{H}_{6},{ }^{3} \mathrm{~J}_{\mathrm{HH}} 7.5 \mathrm{~Hz}\right) .{ }^{13} \mathrm{C}\{\mathrm{H}\}$ NMR $\left(\mathrm{CDCl}_{3}, 125.72 \mathrm{MHz}\right): \delta 61.13\left(\mathrm{C}_{8}\right), 65.25\left(\mathrm{C}_{7}\right), 119.65\left(\mathrm{q}, \mathrm{CF}_{3}\right.$, $\left.{ }^{1} \mathrm{~J}_{\mathrm{FC}} 318.9 \mathrm{~Hz}\right), 128.92\left(\mathrm{C}_{3}\right), 129.02\left(\mathrm{C}_{4}\right), 129.73\left(\mathrm{C}_{6} \mathrm{H}_{5}\right.$-meta $), 130.23$ $\left(\mathrm{C}_{6} \mathrm{H}_{5}\right.$-para $), 131.10\left(\mathrm{C}_{6} \mathrm{H}_{5}\right.$-ortho $), 132.34\left(C_{5}\right), 132.74\left(\mathrm{C}_{6} \mathrm{H}_{5}\right.$-ipso $)$, $138.55\left(C_{6}\right), 149.45\left(C_{2}\right), 181.65\left(C_{1}\right) .{ }^{19} F\{H\}$ NMR: $\delta-77.44 . I R(v, c m$ $\left.{ }^{1}\right):$ 1299, 1197, 1020.

\section{$\left[\mathrm{C}_{6} \mathrm{H}_{5} \mathrm{CH}_{2} \mathrm{~N}\left(\mathrm{CH}_{2} \mathrm{C}_{6} \mathrm{H}_{4}\right)_{2}\right] \mathrm{BiOSO}_{2} \mathrm{C}_{6} \mathrm{H}_{4} \mathrm{CHCH}_{2}-4$ (5)}

From a mixture of $\left[\mathrm{C}_{6} \mathrm{H}_{5} \mathrm{CH}_{2} \mathrm{~N}\left(\mathrm{CH}_{2} \mathrm{C}_{6} \mathrm{H}_{4}\right)_{2}\right] \mathrm{BiBr}(0.103 \mathrm{~g}, 0.179 \mathrm{mmol})$ and silver 4-vinylbenzenesulfonate $(0.052 \mathrm{~g}, 0.179 \mathrm{mmol})$ in acetone $(20 \mathrm{~mL})$, as a colorless solid. Yield: $0.118 \mathrm{~g}(98 \%)$. M.p. $181-183^{\circ} \mathrm{C}$. Anal. Calcd. for $\mathrm{C}_{29} \mathrm{H}_{26} \mathrm{BiNO}_{3} \mathrm{~S}$ ( $\mathrm{MW}=677.57$ ): $\mathrm{C} 51.41, \mathrm{H} 3.87, \mathrm{~N}$ 2.07\%; Found: $\mathrm{C} 51.21, \mathrm{H} 3.68, \mathrm{~N} 2.01 \% .{ }^{1} \mathrm{H}$ NMR $\left(\mathrm{CDCl}_{3}, 500 \mathrm{MHz}\right)$ : $\delta 4.07\left(\mathrm{~s}, 2 \mathrm{H}, \mathrm{H}_{8}\right), 4.35$ ( $\mathrm{AB}$ spin system with $\delta_{\mathrm{A}} 4.22$ and $\delta_{B} 4.48,4 \mathrm{H}$, $\left.\mathrm{H}_{7},{ }^{2} \mathrm{~J}_{\mathrm{HH}} 13.6 \mathrm{~Hz}\right), 5.33\left(\mathrm{~d}, 1 \mathrm{H}, \mathrm{CH}=\mathrm{CH}_{\mathrm{A}} \mathrm{H}_{\mathrm{B}}, \mathrm{H}_{\mathrm{A}},{ }^{3} \mathrm{~J}_{\mathrm{HH}} 10.8 \mathrm{~Hz}\right), 5.82(\mathrm{~d}$, $1 \mathrm{H}, \mathrm{CH}=\mathrm{CH}_{\mathrm{A}} \mathrm{H}_{\mathrm{B}}, \mathrm{H}_{\mathrm{B}},{ }^{3} \mathrm{~J}_{\mathrm{HH}} 17.3 \mathrm{~Hz}$ ), $6.73\left(\mathrm{dd}, 1 \mathrm{H}, \mathrm{CH}=\mathrm{CH}_{\mathrm{A}} \mathrm{H}_{\mathrm{B}},{ }^{3} \mathrm{~J}_{\mathrm{HH}} 17.6\right.$ 
$\left.\mathrm{Hz},{ }^{3} \mathrm{~J}_{\mathrm{HH}} 10.8 \mathrm{~Hz}\right), 7.26-7.29\left(\mathrm{~m}, 2 \mathrm{H}, \mathrm{C}_{6} \mathrm{H}_{5}\right.$-ortho), 7.30 (t, $2 \mathrm{H} \mathrm{C}_{6} \mathrm{H}_{4}$ $\left.\mathrm{H}_{4},{ }^{3} \mathrm{~J}_{\mathrm{HH}} 7.5 \mathrm{~Hz}\right), 7.38-7.42\left(\mathrm{~m}, 2 \mathrm{H} \mathrm{C}_{6} \mathrm{H}_{4}-\mathrm{H}_{3}+1 \mathrm{H} \mathrm{C}_{6} \mathrm{H}_{5}\right.$-para), 7.45 (d, $2 \mathrm{H}, \mathrm{C}_{6} \mathrm{H}_{4}-$ meta, $\left.{ }^{3} \mathrm{~J}_{\mathrm{HH}} 7.1 \mathrm{~Hz}\right), 7.48-7.52\left(\mathrm{~m}, 2 \mathrm{H}, \mathrm{C}_{6} \mathrm{H}_{5}\right.$-meta, $2 \mathrm{H}$, $\mathrm{C}_{6} \mathrm{H}_{4}-\mathrm{H}_{5}$ ), $7.93\left(\mathrm{~d}, 2 \mathrm{H}, \mathrm{C}_{6} \mathrm{H}_{4}\right.$-ortho, ${ }^{3} \mathrm{~J}_{\mathrm{HH}} 7.5 \mathrm{~Hz}$ ), 8.37 (d, $\mathrm{C}_{6} \mathrm{H}_{4}-\mathrm{H}_{6},{ }^{3} \mathrm{~J}_{\mathrm{HH}}$ $7.7 \mathrm{~Hz}) .{ }^{13} \mathrm{C}\{\mathrm{H}\} \mathrm{NMR}\left(\mathrm{CDCl}_{3}, 125.72 \mathrm{MHz}\right): \delta 60.16\left(\mathrm{C}_{8}\right), 63.87\left(\mathrm{C}_{7}\right)$, $115.83\left(\mathrm{CH}=\mathrm{CH}_{\mathrm{A}} \mathrm{H}_{\mathrm{B}}\right), 126.33\left(\mathrm{C}_{6} \mathrm{H}_{4}\right.$-meta $), 126.80\left(\mathrm{C}_{6} \mathrm{H}_{4}\right.$-ortho $)$, $128.54\left(C_{4}\right), 128.70\left(\mathrm{C}_{6} \mathrm{H}_{5}-\right.$ meta $), 129.35\left(C_{3}\right), 129.62\left(\mathrm{C}_{6} \mathrm{H}_{5}-\right.$ para $)$, $131.18\left(\mathrm{C}_{6} \mathrm{H}_{5}\right.$-ortho $), 131.63\left(\mathrm{C}_{5}\right), 132.93\left(\mathrm{C}_{6} \mathrm{H}_{4}, \mathrm{C}-\mathrm{CH}\right), 136.11$ $\left(\mathrm{CH}=\mathrm{CH}_{\mathrm{A}} \mathrm{H}_{\mathrm{B}}\right), 138.60\left(\mathrm{C}_{6}\right), 139.85\left(\mathrm{C}_{6} \mathrm{H}_{5}-i p s o\right), 142.62\left(\mathrm{C}_{6} \mathrm{H}_{4}, \mathrm{C}-\mathrm{SO}_{2}\right)$, $149.22\left(C_{2}\right), 180.51\left(C_{1}\right) . I R\left(v, \mathrm{~cm}^{-1}\right): 1246,1197,1020$.

\section{$\left[\mathrm{C}_{6} \mathrm{H}_{5} \mathrm{CH}_{2} \mathrm{CH}_{2} \mathrm{~N}\left(\mathrm{CH}_{2} \mathrm{C}_{6} \mathrm{H}_{4}\right)_{2}\right] \mathrm{BiONO}_{2}(6)$}

From $\left[\mathrm{C}_{6} \mathrm{H}_{5} \mathrm{CH}_{2} \mathrm{CH}_{2} \mathrm{~N}\left(\mathrm{CH}_{2} \mathrm{C}_{6} \mathrm{H}_{4}\right)_{2}\right] \mathrm{BiBr}(0.208 \mathrm{~g}, 0.353 \mathrm{mmol})$ and $\mathrm{AgNO}_{3}(0.060 \mathrm{~g}, 0.353 \mathrm{mmol})$, as a colorless solid. Yield: $0.19 \mathrm{~g}$ (95\%). M.p. $150{ }^{\circ} \mathrm{C}$ (dec.). Anal. calcd. for $\mathrm{C}_{22} \mathrm{H}_{21} \mathrm{BiN}_{2} \mathrm{O}_{3}(\mathrm{MW}=$ 570.39): C 46.33, H 3.71, N 4.91\%; Found: $\mathrm{C} 46.38, \mathrm{H} 3.74, \mathrm{~N} 4.89 \%$. ${ }^{1} \mathrm{H}$ NMR: $\delta 2.90-2.93\left(\mathrm{~m}, 2 \mathrm{H}, \mathrm{CH}_{2}, \mathrm{CH}_{2} \mathrm{C}_{6} \mathrm{H}_{5}\right), 3.34-3.37(\mathrm{~m}, 2 \mathrm{H}$, $\mathrm{CH}_{2}, \mathrm{H}_{8}$ ), 4.39 ( $\mathrm{AB}$ spin system with $\delta_{\mathrm{A}} 4.33$ and $\delta_{B} 4.45,4 \mathrm{H}, \mathrm{H}_{7},{ }^{2} \mathrm{~J}_{\mathrm{HH}}$ 14.7 Hz), $7.02\left(\mathrm{~d}, 2 \mathrm{H}, \mathrm{C}_{6} \mathrm{H}_{5}\right.$-ortho, $\left.{ }^{3} \mathrm{~J}_{\mathrm{HH}} 7.2 \mathrm{~Hz}\right), 7.27-7.31(\mathrm{~m}, 3 \mathrm{H}$, $\mathrm{C}_{6} \mathrm{H}_{5}$-meta+para), $7.35\left(\mathrm{t}, 2 \mathrm{H}, \mathrm{H}_{4},{ }^{3} \mathrm{~J}_{\mathrm{HH}} 7.3 \mathrm{~Hz}\right), 7.53-7.56\left(\mathrm{~m}, 4 \mathrm{H}, \mathrm{H}_{3}\right.$ $\left.+\mathrm{H}_{5}\right), 8.17\left(\mathrm{~d}, 2 \mathrm{H}, \mathrm{H}_{6},{ }^{3} \mathrm{~J}_{\mathrm{HH}} 7.5 \mathrm{~Hz}\right) .{ }^{13} \mathrm{C}\{\mathrm{H}\}$ NMR: $\delta 34.50\left(\mathrm{C}_{9}\right), 60.33$ $\left(C_{8}\right), 66.41\left(C_{7}\right), 127.80\left(C_{6} H_{5}\right.$-para $), 128.47\left(C_{3}\right), 128.59\left(C_{4}\right), 128.90$ $\left(\mathrm{C}_{6} \mathrm{H}_{5}\right.$-ortho $), 129.30\left(\mathrm{C}_{6} \mathrm{H}_{5}\right.$-meta $), 131.62\left(\mathrm{C}_{5}\right), 136.59\left(\mathrm{C}_{6} \mathrm{H}_{5}\right.$-ipso $)$, $138.13\left(C_{6}\right), 149.10\left(C_{2}\right), 181.59\left(C_{1}\right) . I R\left(v, \mathrm{~cm}^{-1}\right): 1451,1443$.

\section{X-ray structure determination}

Single-crystals of compounds $\mathbf{3}-\mathbf{6}$ were obtained from a mixture of $\mathrm{CH}_{2} \mathrm{Cl}_{2}$ and $\mathrm{n}$-hexane $(1 / 5 \mathrm{v} / \mathrm{v})$ at room temperature. The data were collected on an Oxford Gemini S ( $\mathbf{3}$ and $\mathbf{4}$, at $110 \mathrm{~K}$ ) or a Smart Apex CCDC (5 and 6, at room temperature) diffractometer using Mo K $\alpha$ radiation $(\lambda=0.71073 \AA)$. The calculations were performed using the SHELXS-2013, SHELXL-2016-4 ${ }^{66}$ or the SHELXTL program. ${ }^{67}$ The structures were solved by direct methods and refined by full-matrix least-square procedures on $F^{2}$. All nonhydrogen atoms were refined anisotropically and a riding model was employed in the refinement of the hydrogen atom positions. Crystal and structural refinement data for the crystal structures of compounds $\mathbf{3}$ - $\mathbf{6}$ are given in ESI, Table S2. Intermolecular interactions were identified with PLATON. ${ }^{68}$ The drawings were created with the Diamond software package. ${ }^{69}$

\section{Catalysis}

The oxidation of thiophenol to diphenyl disulfide was performed in a glass batch reactor equipped with a condenser system. Thiophenol (0.001 moles) dissolved in either $10 \mathrm{~mL}$ cyclohexane or $4 \mathrm{~mL}$ 1-butyl-1-methylpyrrolidinium bis(trifluoromethanesulfonyl)imide was stirred at $600 \mathrm{rpm}$ in a silicon bath at $100{ }^{\circ} \mathrm{C}$ under reflux. The catalyst in a loading of $5 \%$ wt. Bi $(2.8 \mathrm{~mol} \% \mathrm{Bi})$ from the reaction mixture was added after the stabilization of the temperature. In order to check the progress of the reaction, samples of $5 \mu \mathrm{L}$ were periodically removed from the reactor, analyzed by GC using a K072320 Termo-Quest chromatograph equipped with a FID detector and a capillary column of $30 \mathrm{~m}$ length and $0.324 \mathrm{~mm}$ in diameter and a DB-5 stationary phase. Highly pure $\mathrm{N}_{2}$ (99.999\%) was used as carrier gas. The reaction product was identified also by GS-MS, using a
GC/MS/MS VARIAN SATURN 2100 T spectrometer equipped with a CP-SIL 8 CB Low Bleed/MS column of $30 \mathrm{~m}$ length and $0.25 \mathrm{~mm}$ diameter.

\section{NMR tube scale reaction}

A mixture of $\left[\mathrm{C}_{6} \mathrm{H}_{5} \mathrm{CH}_{2} \mathrm{CH}_{2} \mathrm{~N}\left(\mathrm{CH}_{2} \mathrm{C}_{6} \mathrm{H}_{4}\right)_{2}\right] \mathrm{BiONO}_{2}(6)\left(0.036 \mathrm{~g}, 6.3 \times 10^{-5}\right.$ $\mathrm{mmol})$, thiophenol $(0.013 \mathrm{ml}, 12.7 \mathrm{mmol})$ and toluene- $\mathrm{d}_{8}(0.5 \mathrm{ml})$ was realized directly in the NMR tube. The solution became slightly yellow in approx. $10 \mathrm{~min}$. Most of the compound 6 remained undisolved. The evolution of the oxidation reaction was followed by VT ${ }^{1} \mathrm{H}$ NMR in the range $20-80^{\circ} \mathrm{C}$ and MS experiments.

\section{Theoretical Calculations}

The geometry optimizations and frequency calculations on compounds $\mathbf{1}$ and $\mathbf{3}$ - $\mathbf{5}$ were performed with Gaussian 09, ${ }^{70}$ Revision E.01 using B3LYP functional, ${ }^{71}$ and def2-TZVP basis set. ${ }^{72}$ The dispersion corrections were accounted using D3 version of Grimme's dispersion with Becke-Johnson damping. ${ }^{73}$ Cartesian coordinates of the calculated molecular structures $\mathbf{1}$ and $\mathbf{3}-\mathbf{5}$ are given in ESI, Tables S3 - S6.

\section{Electronic Supplementary Information}

CCDC 1520802 (3), 1520801 (4) 1520800 (5) and 1520799 (6) contain the supplementary crystallographic data for the investigated compounds. These data can be obtained free of charge from The Cambridge Crystallographic Data Centre via www.ccdc.cam.ac.uk/data_request/cif. The supplementary material also contains the crystal and structural refinement data for the crystal structures of $\mathbf{3}-\mathbf{6}$, interatomic distances and bond angles in compounds $\mathbf{1}-\mathbf{6}$, Figures representing the coordination sphere of $\mathrm{Bi}$ in the crystals of $\mathbf{1}-\mathbf{3}$, Figures representing selected ${ }^{1} \mathrm{H}$ NMR and MS spectra, as well as cartesian coordinates of the calculated molecular structures $\mathbf{1}$ and $\mathbf{3} \mathbf{- 5}$.

\section{Conclusions}

Diorganobismuth(III) compounds of type $\left[\mathrm{C}_{6} \mathrm{H}_{5} \mathrm{CH}_{2} \mathrm{~N}\left(\mathrm{CH}_{2} \mathrm{C}_{6} \mathrm{H}_{4}\right)_{2}\right] \mathrm{BiX}\left[\mathrm{X}=\mathrm{Br}, \mathrm{ONO}_{2}, \mathrm{OSO}_{2} \mathrm{CF}_{3}, \mathrm{OSO}_{2} \mathrm{C}_{6} \mathrm{H}_{4}\right.$ $\left(\mathrm{CHCH}_{2}\right)^{-4]}$, based on a butterfly-like tetrahydrodibenzo $[c, f][1,5]$ azabismocine heterocyclic framework, with anionic ligands with different electron-withdrawing ability proved to be efficient catalysts for the oxidation of thiophenol to diphenyl disulfide under mild conditions with high conversions and chemoselectivity. The catalytic activity in cyclohexane was observed to increase going from the starting diorganobismuth(III) bromides to the derivatives with oxygenated ligands, as a consequence of the stronger electron-withdrawing character of the latter systems. This behaviour was also correlated with a decrease of the $\mathrm{N} \rightarrow \mathrm{Bi}$ distance by changing $\mathrm{Br}$ (about $2.531 \AA$ ) with oxygenated ligands [range $2.402(3)-2.479(5) \AA]$. It is clear that the overall catalytic activity is strongly influenced by a combination of factors including the acid/base character of the diorganobismuth(III) complex, the polarizability of the Bi-X $(X=$ $\mathrm{O}, \mathrm{Br}$ ) bond and the accessibility to the metal centre. 
Catalytic experiments carried out in 1-butyl-1methylpyrrolidinium bis(trifluoromethanesulfonyl)imide showed a positive influence of the ionic liquid leading to higher reaction rates with the same selectivity to diphenyl disulfide. This effect is explained by the higher solubility of oxygen in the ionic liquid than in cyclohexane, as well as by the ionization of the catalytic species promoted by the IL.

Taking into account the calculated charge on bismuth ( 0.790 for $\mathrm{Br}$ and over 0.9 for the oxygenated ligands), as well as the experimental catalytic results, it might be concluded that the increased polarity of the $\mathrm{Bi}-\mathrm{O}$ bond compared to the $\mathrm{Bi}-\mathrm{Br}$ one, make the complexes with oxygenated ligands more suitable for catalysis, either in cyclohexane or in ionic liquid.

The ${ }^{1} \mathrm{H} N M R$ and ESI+ MS experiments carried out for a $1: 2$ (molar ratio) mixture in toluene- $d_{8}$ solution support a two steps reaction pathway, involving the intermediary formation of diorganobismuth(III) phenylthiolates.

\section{Acknowledgements}

Financial support from National University Research Council of Romania CNCSIS (Research Project PNII-ID-PCCE-2011-20050/Partner 3), from DFG SPP1807 "Control of London Dispersion Interactions in Molecular Chemistry" and from the Fonds der Chemischen Industrie (FCl) is greatly acknowledged. A.T. is grateful for financial support from DAAD (fellowship, "Eastern Europe Partnership" program and STIBET). Theoretical calculations were performed on high-performance computational facility MADECIP, POSCCE, COD SMIS $48801 / 1862$ co-financed by the European Regional Development Fund of the European Union.

\section{Notes and references}

1 (a) U. Pathak, L.K. Pandey, S. Mathur, Synth. Commun., 2009, 39, 2923; (b) R.J. Cremlyn (Ed.), An Introduction to Organosulfur Chemistry, Wiley \& Sons, New York, 1996; (c) A. Dhakshinamoorthy, M. Alvaro, H. Garcia, Chem. Commun., 2010, 46, 6476.

2 (a) P.C. Jocelyn, Biochemistry of the Thiol Group, Academic Press, New York, 1977; (b) Y. Kanda, T. Fukuyama, J. Am. Chem. Soc., 1993, 115, 8451; (c) G. Pattenden, A. Shuker, J. Chem. Soc. Perkin Trans., 1992, 1, 1215; (d) E. Block, Angew. Chem. Int. Edn. Engl., 1992, 31, 1135.

3 (a) Z. Guo, B. Liu, Q. Zhang, W. Deng, Y. Wang, Y. Yang, Chem. Soc. Rev., 2014, 43, 3480; (b) F. Cavani, Catal. Today, 2010, 157, 8.

4 A. Talla, B. Driessen, N.J.W. Straathof, L.-G. Milroy, L. Brunsveld, V. Hessel, T. Noel, Adv. Synth. Catal., 2015, 357, 2180; (b) S. Dharmarathna, C. K. Kingondu, L. Pahalagedara, C.-H. Kuo, Y. Zhang, S.L. Suib, Appl. Catal. B, 2014, 147, 124.

5 J.-E. Bäckvall, (Ed), Modern Oxidation Methods, Wiley-VCH, Hoboken, NJ, 2011.

6 (a) A. Dhakshinamoorthy, M. Alvaro, H. Garcia, Chem. Commun., 2010, 46, 6476; (b) D.R. Dreyer, H.-P. Jia, A.D. Todd, J. Geng, C. W. Bielawski, Org. Biomol. Chem., 2011, 9, 7292.

7 Y.P. Bhoi, D.P. Rout, B.G. Mishra, J. Clust. Sci., 2015, 27, 267.

8 M. Montazerozohori, S. Joohari, B. Karami, N. Haghighat, Molecules, 2007, 12, 694.
9 A.R. Hajipour, S.E. Mallakpour, H. Adibi, J. Org. Chem., 2002, 67, 8666 .

10 S.L.S. Leite, V.L. Pardini, H. Viertler, Synth. Commun., 1990, 20, 393.

11 (a) A. Sabet, A. Fakhraee, M. Ramezanpour, N. Alipour, International Journal of Chemical, Molecular, Nuclear, Materials and Metallurgical Engineering 2014, 8, 1184; (b) V. Cimpeanu, V.I. Pârvulescu, P. Amoros, D. Beltran, S. Johnson, C. Hardacre, Chem-Eur J., 2004, 10, 4640; (c) V. Cimpeanu, A.N. Parvulescu, V.I. Pârvulescu, D.T. On, S. Kaliaguine, J.M. Thompson, C. Hardacre, J. Catal., 2005, 232, 60.

12 (a) T. Aida, T. Akasaka, N. Furukawa, S. Oae, Bull. Chem. Soc. Jpn., 1976, 49, 1441; (b) J.R. Schaeffer, C.T. Goodhue, H.A. Risley, R.E. Stevens, J. Org. Chem., 1967, 32392.

13 (a) T.J. Wallace, J. Org. Chem., 1966, 31, 3071; (b) J. Choi, N. M. Yoon, J. Org. Chem., 1995, 60, 3266; (c) P. Salehi, A. Farrokhi, M. Gholizadeh, Synth. Commun., 2001, 31, 2777; (d) N.A. Noureldin, M. Caldwell, J. Hendry, D.G. Lee, Synthesis, 1998, 11, 1587.

14 R.S. Varma, H.M. Meshram, R. Dahiya, Synth. Commun., 2000, 30, 1249.

15 S. Tsuneo, O. Junzo, N. Hitosi, Tetrahedron Lett., 1990, 31 3591.

16 K.-T. Liu, Y.-C. Tong, Synthesis, 1978, 669.

17 B.J. Evans, J.T. Doi, W.K. Musker, J. Org. Chem., 1990, 55, 2337.

18 (a) W.A. Pryor, D.F. Church, C.K. Govindan, G. Crank, J. Org. Chem., 1982, 47, 156; (b) N. Iranpoor, H. Firouzabadi, A.-R. Pourali, Tetrahedron, 2002, 58, 5179.

19 (a) H. Golchoubian, F. Hosseinpoor, Catal. Commun., 2007, 8 , 697; (b) M. Kirihara, K. Okubo, T. Uchiyama, Y. Kato, Y. Ochiai, S. Matsushita, A. Hatano, K. Kanamori, Chem. Pharm. Bull., 2004, 52, 625; (c) M. Kirihara, Y. Asai, S. Ogawa, T. Noguchi, A. Hatano, Y. Hirai, Synthesis, 2007, 3286; (d) M. Chakraborty, P.C. Mandal, S. Mukhopadhyay, Polyhedron, 2012, 45, 213; (e) M. Hayashi, K. Okunaga, S. Nishida, K. Kawamura, K. Eda, Tetrahedron Lett., 2010, 51, 6734; f) C. Tidei, M. Piroddi, F. Galli, C. Santi, Tetrahedron Lett., 2012, 53, 232.

20 (a) M. Montazerozohari, B. Karami, M. Azizi, Arkivoc, 2007, 1, 99; (b) M. Zolfigol, F. Shirini, K. Zamani, E. Ghofrani, S. Ebrahimi, Phosphorus Sulfur Silicon Relat. Elem., 2004, 179, 2177; (c) M.A. Zolfigol, Tetrahedron, 2001, 57, 9509.

21 (a) H. Egami, T. Katsuki, J. Am. Chem. Soc., 2007, 129, 8940; (b) K. Jeyakumar, D.K. Chand, Tetrahedron Lett., 2006, 47, 4573; (c) R. Sanz, R. Aguado, M.R. Pedrosa, F.J. Arnaiz, Synthesis, 2002, 856; (d) A. Corma, H. Garcia, Chem. Soc. Rev., 2008, 37, 2096.

22 (a) A. Saxena, A. Kumar, S. Mozumdar, J. Mol. Catal. A: Chem., 2007, 269, 35; (b) E.J. Lenardao, R.G. Lara, M.S. Silva, R.G. Jacob, G. Perin, Tetrahedron Lett., 2007, 48, 7668; (c) M.A. Walters, J. Chaparro, T. Siddiqui, F. Williams, C. Ulku, A. L. Rheingold, Inorg. Chim. Acta, 2006, 359, 3996; (d) M.A. Zolfigol, Tetrahedron, 2001, 57, 9509.

23 A.M. Kulkarni, U.V. Desai, K.S. Pandit, M.A. Kulkarni, P.P. Wadgaonkar, RSC Adv., 2014, 4, 36702.

24 P. Kumar, G. Singh, D. Tripathi, S.L. Jain, RSC Adv., 2014, 4, 50331.

25 M. Sridhar, S.K. Vadivel, U.T. Bhalerao, Synth. Commun., 1998, 28, 1499.

26 B. Karami, M. Montazerozohori, M. Moghadam, M.H. Habibi, K. Niknam, Turk. J. Chem., 2005, 29, 539.

27 (a) J. Luan, L. Zhang, Z. Hu, Molecules, 2011, 16, 4191; (b) H. Gaspard-lloughmane, C.L. Roux, Eur. J. Org. Chem., 2004, 2517; (c) N.M. Leonard, L.C. Wieland, R.S. Mohan, Tetrahedron, 2002, 58, 8373; (d) H. Suzuki, Y. Matano (Eds.), Organobismuth Chemistry, Elsevier, Amsterdam, 2001. (e) T. Ollevier, Org. Biomol. Chem., 2013, 11, 2740 and references 
therein; (f) T. Ollevier (Ed.), Bismuth-Mediated Organic Reactions, Springer-Verlag, Berlin, Heidelberg, 2012.

28 M.M. Khodaei, I. Mohammadpoor-Baltork, K. Nikoofar, Bull. Korean Chem. Soc., 2003, 24, 885.

29 (a) R. Qiu, Y. Chen, S.-F. Yin, X. Xu, C.-T. Au, RSC Adv., 2012, 2, 10774; (b) H.R. Kricheldorf, Chem. Rev., 2009, 109, 5579.

30 H.J. Breunig, N. Haddad, E. Lork, M. Mehring, C. Mügge, C. Nolde, C.I. Raţ, M. Schürmann, Organometallics, 2009, 28 1202.

31 C. Silvestru, H.J. Breunig, H. Althaus, Chem. Rev., 1999, 99, 3277.

32 (a) R. Qiu, S. Yin, X. Zhang, J. Xia, X. Xu, S. Luo, Chem. Commun., 2009, 4759; (b) R. Qiu, S. Yin, X. Song, Z. Meng, Y. Qiu, N. Tian, X. Xu, S. Luo, F.-R. Dai, C.-T. Au, W.-Y. Wong, Dalton Trans., 2011, 40, 9482.

33 (a) R. Qiu, Y. Qiu, S. Yin, X. Xu, S. Luo, C.-T. Au, W.-Y. Wong, S. Shimada, Adv. Synth. Catal., 2010, 352, 153; (b) R.H. Qiu, Y. M. Qiu, S.F. Yin, X.X. Song, Z.G. Meng, X.H. Xu, X.W. Zhang, S.L. Luo, C.-T. Au, W.-Y. Wong, Green Chem., 2010, 12, 1767.

34 (a) X.W. Zhang, S.F. Yin, R.H. Qiu, J. Xia, W. L. Dai, Z.Y. Yu, C.T. Au, W.Y. Wong, J. Organometal. Chem., 2009, 694, 3559; (b) X.W. Zhang, R.H. Qiu, N.Y. Tan, S.F. Yin, J. Xia, S.L. Luo, C.T. Au, Tetrahedron Lett., 2010, 51, 153.

35 I.T. Horváth, P.T. Anastas, Chem. Rev., 2007, 107, 2169.

36 J.H. Clark, S.J. Tavener, Org. Process Res. Dev., 2007, 11, 149.

37 (a) V.I. Parvulescu, C. Hardacre, Chem. Rev., 2007, 107, 2615; (b) H. Olivier-Bourbigou, L. Magna, D. Morvan, Appl. Catal. A.-Gen., 2010, 373, 1; (c) R. Hayes, G.G. Warr, R. Atkin, Chem. Rev., 2015, 115, 6357; (d) N.V. Plechkovaa, K.R. Seddon, Chem. Soc. Rev., 2008, 37, 123.

38 (a) G. Chatel, R.D. Rogers, ACS Sustainable Chem. Eng., 2014, 2, 322; (b) W. Qian, E. Jin, W. Bao, Y. Zhang, Angew. Chem. Int. Ed., 2005, 44, 952; (c) D. Betz, P. Altmann, M. Cokoja, W.A. Herrmann, F.E. Kühn, Coord. Chem. Rev., 2011, 255, 1518; (d) S.M. Coman, M. Florea, V.I. Parvulescu, V. David, A. Medvedovici, D. de Vos, P.A. Jacobs, G. Poncelet, P.Grange, J. Catal., 2007, 249, 359.

39 S. Thurow, V.A. Pereira, D.M. Martinez, D. Alves, G. Perin, R. G. Jacob, E.J. Lenardão, Tetrahedron Lett., 2011, 52, 640.

40 A.R. Hajipour, M. Mostafavi, A.E. Ruoho, Phosphorus Sulfur, 2009, 184, 1920.

41 S.M.S. Chauhan, A. Kumar, K.A. Srinivas, Chem. Commun., 2003, 2348.

42 D. Zhao, Y. Wang, Erhong Duan, Molecules, 2009, 14, 4351.

43 W. Zhu , H. Li , X. Jiang, Y. Yan , J. Lu , J. Xia, Energ. Fuel., 2007, 21, 2514.

44 D. Zhao, J. Wang, E. Zhou, Green. Chem., 2007, 9, 1219.

45 W. Zhu, G. Zhu, H. Li, Y. Chao, Y. Chang, G. Chen, C. Han, J. Mol. Catal. A.-Chem., 2011, 347, 8.

46 G. Yu, J. Zhao, D. Song, C. Asumana, X. Zhang, X. Chen, Ind. Eng. Chem. Res., 2011, 50, 11690.

47 A. M. Toma, A. Pop, A. Silvestru, T. Rüffer, H. Lang, M. Mehring, Dalton Trans., 2017, 46, 3953-3962.

48 (a) H.J. Breunig, M.G. Nema, C. Silvestru, A.P. Soran, R.A. Varga, Dalton Trans., 2010, 39, 11277; (b) R.P. Oertel, R.A. Plane, Inorg. Chem., 1968, 7, 1192.

49 Y. Matano, T. Miyamatsu, H. Suzuki, Organometallics, 1996, 15, 1951.

50 X.-W. Zhang, J. Xia, H.-W. Yan, S.-L. Luo, S.-F. Yin, C.-T. Au, W.-Y. Wong, J. Organomet. Chem., 2009, 694, 3019.

51 S. Shimada, O. Yamazaki, T. Tanaka, Y. Suzuki, M. Tanaka, J. Organomet. Chem., 2004, 689, 3012.

52 IUPAC Nomenclature of Organic Chemistry, Pergamon Press, Oxford, 1979.

53 The $N-X-L$ nomenclature system has been previously described: $N$ valence shell electrons about a central atom $X$ with L ligands. C. W. Perkins, J. C. Martin, A. J. Arduengo III,
W. Lau, A. Alegria and K. Kochi, J. Am. Chem. Soc., 1980, 102, 7753.

54 (a) A. A. Auer, D. Mansfeld, C. Nolde, W. Schneider, M. Schürmann, M. Mehring, Organometallics, 2009, 28, 5405; (b) I. Caracelli, J. Zukerman-Schpector, I. Haiduc and E.R.T. Tiekink, CrystEngComm, 2016, 18, 6960.

55 P.V. Ioannou, Main Group Chemistry, 2013, 12, 125.

56 (a) C. Hansch, A. Leo, R. W. Taft, Chem. Rev., 1991, 91, 165. (b) K. Ohkata, S. Takemoto, M. Ohnishi and K. Akiba, Tetrahedron Lett., 1989, 30, 4841.

57 I. Bahadur, K. Osman, C. Coquelet, P. Naidoo, D. Ramjugernath, J. Phys. Chem. B, 2015, 119, 1503.

58 O.D. Pavel, P. Goodrich, L. Cristian, S.M. Coman, V.I. Pârvulescu, C. Hardacre, Catal. Sci. Technol., 2015, 5, 2696.

59 A. Corma, T. Rodenas and M.J. Sabater, Chem. Sci., 2012, 3, 398.

60 A. Dhakshinamoorthy, A.M. Asiri, J.R. Herance, H. Garcia, Catal. Today, 2016, https://doi.org/10.1016/j.cattod.2017.01.018

61 C. Esmieu, M. Orio, L. Le Pape, C. Lebrun, J. Pécaut, S. Ménage and S. Torelli, Inorg. Chem., 2016, 55, 6208.

62 P.K. Shyam, Y.K. Kim, C. Lee, H.-Y. Jang, Adv. Synth. Catal. 2016, 358, 56.

63 (a) G. G. Briand, A. Decken, N. M. Hunter, G. M. Lee, J. A. Melanson, E. M. Owen, Polyhedron, 2012, 31, 796; (b) P. Simon, R. Jambor, A. Ruzicka, L. Dostal, Organometallics, 2013, 32, 239.

64 D. Zhao, Z. Fei, R. Scopelliti, P. Dyson, J. Inorg. Chem., 2004, 43, 2197.

65 MestReC and MestReNova, Mestrelab Research S.L., A Coruña 15706, Santiago de Compostela.

66 G.M. Sheldrick, Acta Crystallogr., Sect. A: Found. Crystallogr. 2008, 64, 112.

67 G.M. Sheldrick, SHELXTL 5.1, An Integrated System for Solving, Refining and Displaying Crystal Structures from Diffraction Data, Siemens Analytical X-ray Instruments, Madison, WI, 1990.

68 PLATON (a) A. L. Spek, J. Appl. Cryst., 2003, 36, 7; (b) A.L. Spek, Acta Crystallogr., Sect. D: Biol. Crystallogr. 2009, 65, 148; (c) A.L. Spek, Acta. Cryst C., 2015, 71, 9.

69 DIAMOND-Visual Crystal Structure Information System, Crystal Impact: Postfach 1251, D-53002 Bonn, Germany, 2001.

70 M.J. Frisch, G.W. Trucks, H.B. Schlegel, G.E. Scuseria, M.A. Robb, J.R. Cheeseman, G. Scalmani, V. Barone, B. Mennucci, G.A. Petersson, H. Nakatsuji, M. Caricato, X. Li, H.P. Hratchian, A.F. Izmaylov, J. Bloino, G. Zheng, J.L. Sonnenberg, M. Hada, M. Ehara, K. Toyota, R. Fukuda, J. Hasegawa, M. Ishida, T. Nakajima, Y. Honda, O. Kitao, H. Nakai, T. Vreven, J. A. Montgomery, Jr., J.E. Peralta, F. Ogliaro, M. Bearpark, J.J. Heyd, E. Brothers, K.N. Kudin, V.N. Staroverov, T. Keith, R. Kobayashi, J. Normand, K. Raghavachari, A. Rendell, J.C. Burant, S.S. Iyengar, J. Tomasi, M. Cossi, N. Rega, J.M. Millam, M. Klene, J.E. Knox, J.B. Cross, V. Bakken, C. Adamo, J. Jaramillo, R. Gomperts, R.E. Stratmann, O. Yazyev, A.J. Austin, R. Cammi, C. Pomelli, J.W. Ochterski, R.L. Martin, K. Morokuma, V.G. Zakrzewski, G.A. Voth, P. Salvador, J.J. Dannenberg, S. Dapprich, A.D. Daniels, O. Farkas, J.B. Foresman, J.V. Ortiz, J. Cioslowski, D.J. Fox, Gaussian 09, Revision E.01, Gaussian, Inc., Wallingford CT, 2013.

71 A.D. Becke, J. Chem. Phys., 1993, 98, 5648.

72 F. Weigend, R. Ahlrichs, Phys. Chem. Chem. Phys., 2005, 7, 3297.

73 S. Grimme, S. Ehrlich, L. Goerigk, J. Comp. Chem., 2011, 32, 1456. 


\section{Synopsys}

Aerial oxidation of thiophenol to diphenyl disulfide proceeds with high reaction rates, total conversion and selectivity in ionic liquids by using diorganobismuth(III) catalysts based on a tetrahydrodibenzo[c,f][1,5]azabismocine heterocyclic framework.

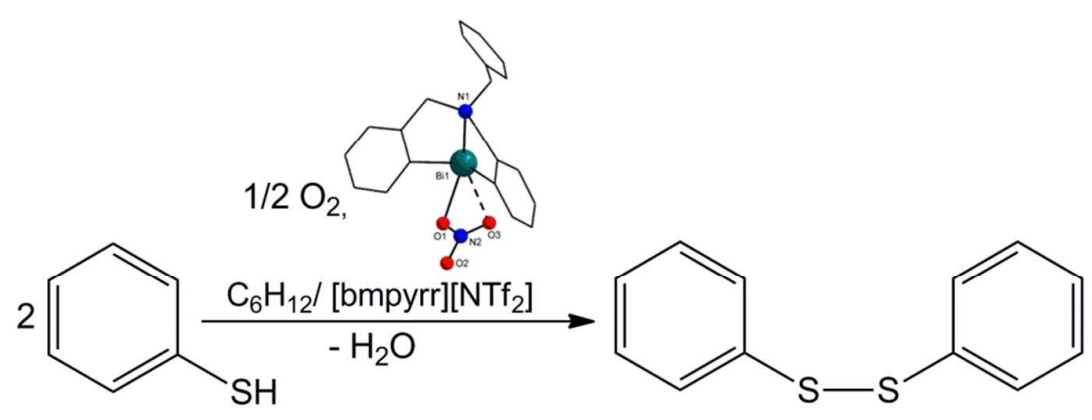

